\title{
Improving our ability to model crystalline aquifers using field data combined with a regionalized approach for estimating the hydraulic conductivity field
}

Benoît Dewandel $^{1,2^{*}}$, Alexandre Boisson $^{3}$, Nadia Amraoui ${ }^{4}$, Yvan Caballero ${ }^{1,2}$, Bruno Mougin $^{3}$, Jean-Michel Baltassat ${ }^{4}$, Jean-Christophe Maréchal ${ }^{1,2}$

1- BRGM, Univ Montpellier, Montpellier, France

2- G-eau, UMR 183, INRAE, CIRAD, IRD, AgroParisTech, Supagro, BRGM, Montpellier, France.b.dewandel@brgm.fr; y.caballero@brgm.fr; jc.marechal@brgm.fr.

3- BRGM, DAT/GDO/BRE. 2 rue Jouanet 35700 Rennes, France a.boisson@brgm.fr; b.mougin@brgm.fr.

4- BRGM, DEPA/GDR. 3 Av. C. Guillemin, 45060 Orléans. n.amraoui@brgm.fr

5- BRGM, DRP/IGT. 3 Av. C. Guillemin, 45060 Orléans. jm.baltassat@brgm.fr

* Corresponding author

\begin{abstract}
Modelling of heterogeneous aquifers, such as crystalline aquifers, is often difficult and, flow and transport predictions are always uncertain, suffering of our imperfect knowledge of the spatial distribution of aquifer parameters. This paper aims to test the robustness of a firstorder hydraulic conductivity map estimated from both a detailed water-table map and hydraulic-conductivity statistics on a granitic watershed in Brittany $\left(57 \mathrm{~km}^{2}\right)$, compare it to local estimates and assess it through various numerical models. Map values range on four orders of magnitude $\left(10^{-7}\right.$ to $10^{-4} \mathrm{~m} / \mathrm{s}$, mean: $\left.3.9 \times 10^{-6} \mathrm{~m} / \mathrm{s}\right)$ and their comparison to local estimates from various sources (pumping tests, MRS measurements, streamflow) gives satisfactory results.
\end{abstract}

Four hydraulic conductivity fields were assessed through numerical modelling under steadystate condition. Model 1 used the regionalized hydraulic conductivity field directly, Model 2 used a uniform value (average of Model 1), Model 3 used a hydraulic conductivity field obtained by inverse modelling of the water table and Model 4 used two zones of uniform values based on the analysis of Model 1 and Model 3 fields. Model results were analysed based on their ability to reproduce the observed water-table levels and the groundwater flow directions. Modelled groundwater discharges to streams at sub-catchment scale were compared to spatial streamflow measurements performed during low water condition, which 
help validating models. The comparison between the fields obtained from Model 3 and that from the regionalized method (Model 1) shows that they are close in terms of mean values and spatial distribution. Model 1 reproduces rather well the water-table map and the groundwater flow directions. Model 2 shows the less good results. . Model 4 has led to satisfactory results and shows that the hydraulic conductivity is higher $\left(2.1 \times 10^{-6} \mathrm{~m} / \mathrm{s}\right)$ where the water table is located in the fractured zone, and lower $\left(3.3 \times 10^{-7} \mathrm{~m} / \mathrm{s}\right)$ where it is located in the saprolites (highly weathered rock), which is expected for such aquifer system. Modelled groundwater discharges to streams are comparable in all models to streamflow measurements in most sub-catchments, but the models overestimate them in certain places, mainly because of sub-surface drains in a forest capturing part of the groundwater that can no longer return to streams (drains were not considered in the models).

In addition, experiment on a second watershed $\left(40 \mathrm{~km}^{2}\right)$ shows how with much less field data the methodology can already provide interesting information on the hydraulic conductivity field (values and spatial distribution)..

Results are very encouraging and open up prospects for using quantitative and qualitative information from the mapping of hydraulic conductivity to constrain the spatialization of hydrodynamic parameters on models and thus our ability to model such complex aquifers.

Keywords: Regionalization of hydraulic conductivity, crystalline aquifers, Hard-rock aquifers, modelling

\section{Introduction}

Nowadays, the modelling of groundwater systems is recognized as the best tool to manage and optimize the use of groundwater resources. However, even if in the last 30 years there has been an increasing number of numerical codes or models (softwares), more and more sophisticated and able to integrate huge sets of data in order to address a large panel of waterrelated problems, flow and transport predictions are still subject to large uncertainties, suffering mainly from our imperfect knowledge of aquifer properties. Though it is relatively easy to evaluate these properties at a local scale, for instance deducing hydraulic conductivity and storage coefficient from hydraulic tests, it is more difficult to assess their variability at the aquifer-system scale, where spatial variations may occur over several orders of magnitude. 
In crystalline aquifers, the regionalization of hydrogeological properties makes the problem much more complex because of their strong natural heterogeneity, e.g. hydraulic conductivity can vary over 12 orders of magnitude (Tsang et al., 1996; Hsieh, 1998). Indeed, various degrees in fracturing and connection between fracture networks induce strong variations of properties at all scales (e.g., Paillet, 1998; Maréchal et al., 2004; Le Borgne et al., 2004, 2006; Boutt et al., 2010; Guihéneuf et al., 2014; Boisson et al., 2015, etc.). Moreover, where exposed to deep weathering processes, such rocks develop several stratiform layers, parallel to the weathering surface. Layers are mainly a saprolites layer (highly weathered parent rocks of low-permeability) and an overlying fractured layer (most permeable), in which hydrogeological properties are closely related to the degree of weathering (Taylor and Howard, 2000; Wyns et al., 2004; Dewandel et al., 2006; Lachassagne et al., 2011, 2021). Despite this strong natural heterogeneity, even in the latest modelling studies on crystalline aquifers, a single property value is assigned to each layer or on large compartments (Join et al., 2005; Ahmed and Sreedevi, 2008; Rivard et al., 2008; Goderniaux et al., 2013; Leray et al., 2013; Kolbe et al., 2016; Marçais et al.; 2017; Durand et al., 2017; Dewandel et al., 2017a; Dickson et al., 2018; Bianchi et al., 2020). Whether built to test conceptual models for the understanding of such complex aquifers, to assess the flow distribution or residence-times at various scales, to evaluate average aquifer properties, to predict aquifer productivity or to define a sustainable management of the water resource, these studies illustrate our difficulties to introduce the spatial variations of hydrodynamic properties in models. Few studies have considered the spatial variation of aquifer properties at aquifer scale (Lubczynski and Gurwin, 2005; Yidana et al., 2013). However, their results in terms of spatial variations of hydrogeological properties remain unclear, sometimes more related to inversion hypothesis (modelling hypotheses, boundary conditions...) than to real hydrogeological characteristics. Despite computer progress, these works stress our difficulty in crystalline aquifers -or for other type of fractured aquifers, to propose realistic hydrogeological properties fields, probably due to a lack of robust methodologies for their evaluation prior to modelling. It is thus of crucial importance for practical applications to reduce these uncertainties.

Over the past decades, various methods, combining hydrodynamic parameters, geostatistics, geological facies, inverse modelling techniques, geophysical data, etc., have been proposed for estimating hydraulic conductivity, transmissivity or storativity at the scale of groundwater systems (e.g. Carrera and Neuman, 1986; Carrera et al., 2005; de Marsily et al., 2005; Vermeulen et al., 2005; Straface et al., 2011; Illman, 2014). However, most of these methods 
require extensive field surveys and were designed for alluvial and sedimentary aquifers. In crystalline aquifers, a few studies describe the spatial heterogeneity of aquifer parameters and mainly focus on transmissivity or hydraulic-conductivity mapping based on data from hydraulic tests (Razack and Lasm, 2006; Chandra et al., 2008; Dickson et al., 2018), on classified transmissivity (i.e. indexed) maps, or on potential aquifer-zone maps (Krásný, 1993; Krásný, 2000; Lachassagne et al., 2001; Darko and Krásný, 2007; Madrucci et al., 2008; Dhakate et al., 2008; Courtois et al., 2010). Other methods based on hydraulic tomography provide promising results to describe the heterogeneity of hydraulic conductivity and storage coefficient in fractured rocks, but also require a large amount of field data (Illman, 2014). More recently, other approaches have been proposed, based on the concept that large-scale variations in hydraulic head may characterize large-scale aquifer properties (Dewandel et al., $2012,2017 b, c)$. In these approaches, the regionalization of hydraulic conductivity was based either on statistical relationships between the hydraulic conductivity from small-scale tests and linear-discharge rates from numerous pumped wells (Dewandel et al., 2012), or on detailed analysis of water-table maps in areas where there is no pumping well, but with a high density of water-table observations (Dewandel et al., 2017b). In the absence of recharge from rainfall, methods for effective porosity were developed in 2-D, for that part of the aquifer where the water table fluctuates (Dewandel et al., 2012), and in 3-D to the entire aquifer thickness while introducing the geometrical structure of the weathering profile (Dewandel et al., 2017c; Mizan et al., 2019). Those methods combines - at a cell scale-water-table fluctuation and groundwater-budget techniques, and an aggregation method. These methods for regionalizing hydraulic conductivity and effective porosity were tested on several crystalline aquifers exposed to deep weathering in southern India (granites; 50-1000 $\mathrm{km}^{2}$ ) and in New Caledonia (peridotites; $3.5 \mathrm{~km}^{2}$ ), showing very good estimates when compared to existing field data (Dewandel et al., 2012, 2017b, c). The generated hydrodynamic parameters fields, although not intended to be perfectly exact, can help identifying the spatial pattern of parameters, thus providing valuable information on aquifer heterogeneity. Although hydrodynamic parameters maps provide new insights to identify potential draining zones, to site bore wells, or to produce groundwater storage maps that find practical applications for establishing water protection zones and improving groundwater management policies, the robustness of the evaluated parameters was not confronted with numerical modelling.

The objective of this paper is to assess the robustness of a hydraulic conductivity map estimated from both a detailed water table map and hydraulic conductivity statistics on a 
granitic watershed in Brittany, Nançon watershed (57 km², France, Fig.1a). The map, which is a first-order result, has been compared to local estimates deduced from hydraulic tests, magnetic resonance soundings and streamflow measurements. Then, the map has been tested with hydrodynamic modelling (steady-state condition), allowing to account for its relevance and to test the sensitivity of the approach carried out. Several models were tested to explore various ways of using the produced hydraulic conductivity map. An original point, compared to previous studies, is the use of spatial streamflow measurements during the low water period to help validating models.

In addition, it is shown on a second watershed (Maudouve-Noë Sèche $40 \mathrm{~km}^{2}$, Fig.1b) how, with much less field data, the methodology can already provide interesting information on the hydraulic conductivity field. The main results for this watershed are presented in the discussion. The main information concerning this second watershed is provided as Supporting Information.

\section{Field data}

\subsection{Location, climate and general settings}

The Nançon catchment, $57 \mathrm{~km}^{2}$, lies $50 \mathrm{~km}$ Northeast of Rennes city in the Brittany region, France (Ille-et-Vilaine department, Fig.1a). The area has a gently rolling relief with elevation ranging between 110 and 230 m.a.s.l. (meters above sea level; Fig.1a). The region experiences an oceanic climate with mean annual rainfall of $940 \mathrm{~mm}$, from which most of them are received from September to April. Low water period occurs from June to October, during this period recharge from rainfall to the aquifers is very low to nil, particularly in July and August (Dewandel et al., 2020). This is a rural area where a forest occupies a large part of the South of the watershed (Fougères forest). The exploitation of groundwater is moderate and most of the boreholes are used for agricultural needs (livestock farming); Fig.1a. However, a few structures exploit groundwater for drinking water supply, in particular drains in the forest of Fougères. These trenches, 3 to 5 meters deep, capture some springs and sub-surface flows within the saprolites layer (highly weathered superficial material), and therefore not the aquifer in the strict sense (i.e. the fractured aquifer). They form a dendritic network of about $12 \mathrm{~km}$ with poorly known geometry and abstraction (e.g. length and abstraction of each branch); the first trenches of which were built in the 17th century. The total groundwater abstraction is about $1.46 \mathrm{Mm}^{3} /$ year, of which $1.31 \mathrm{Mm}^{3} /$ year are due to the trenches. 


\subsection{Geology}

165

The geology of the area is relatively homogeneous and consists of granitic rocks, biotite granodiorite to the North and biotite-cordierite granodiorite to the South, two granodiorites with slightly different mineralogical contents (Mougin et al., 2008; Fig.1a). To the South of the basin, there is, but in a very poorly represented way, the hornfels schists of Fougères, which are metamorphosed Brioverian schists. In the center, there is a small Tertiary age basin made up of Landéan clays (sedimentary rocks). This will not be the object of spatialization of hydrodynamic properties or of particular modelling.

Crystalline rocks are affected by deep in situ weathering that forms of a saprolites layer and an underlying fractured layer. Layers (Figure 2a \& b; Mougin et al., 2008) were mapped according to geological log database (64 logs of wells intersecting the bottom of the saprolites; BRGM-French geological survey database) and numerous field observations (585). Saprolites are very widespread in the watershed, and composed of ochre-brown clay sands whose facies varies relatively little at the watershed scale. Their thickness is on average $4 \mathrm{~m}$ with locally in plateau area thicknesses exceeding twenty meters (Fig.2a). The underlying fractured layer is on average $35-40 \mathrm{~m}$ thick, and exceeds $60 \mathrm{~m}$ thick in some areas. In the valleys, it may directly outcrop due to erosion of the overlying saprolites. On average, at the watershed scale, the total weathering profile (saprolites + fractured zone) is around 40 meters thick (Fig.2b). A few NNW-SSE faults compartmentalize the profile, giving to the weathering profile a "piano key" structure. Shifts induced by faults are nevertheless modest, ranging from a few meters to around ten meters.

\subsection{Available hydrogeological data}

\subsubsection{Water table map}

A water table map (Fig. 3a) was drawn based on groundwater level measurements from 99 wells in August 2017 during the dry season ('snapshot map'), therefore in absence of significant rainfall and in absence of recharge from rainfall. Measurements were carried out on unexploited wells, most of the time old wells about ten meters deep reaching the top of the fractured layer. These wells are screened both in the saprolites (where present) and the fractured layer. In the area, annual water level fluctuations at the watershed scale is about $1 \mathrm{~m}$ 
(Dewandel et al., 2020). In August 2017, water levels were shallow, at $1.4 \mathrm{~m}$ below ground level on average, and are more or less parallel to the topographic surface. They are not significantly impacted by pumping wells. Overall, water-table lies in the top of the fractured layer on valleys, and mainly within the saprolites layer on plateaus. In order to provide a relevant mapping, variogram- based statistics and kriging techniques were used (e.g. Razack and Lasm, 2006); Fig.3a, c. As the aquifer is unconfined (absence of an impermeable layer at the aquifer top), water-table depth were interpolated rather than water-table levels. Moreover, as the aquifer is connected to streams (eg. Fig.4c shows a constant increase of streamflow at the watershed scale because aquifers feed the stream), kriging was constrained by streams, forcing the groundwater levels to pass through them. Note that this constraint does not impose a flow-direction between the aquifer and the stream. For example, upstream the aquifer may feed the streams, while downstream the streams may recharge the aquifers. As mapping was done on water level depth, a zero value was imposed on the course of streams. Then, the water-table map was obtained by simple difference to DEM over a 500x500 m cell grid (Fig.1a; Fig.3a). This method explains the irregular nature of contour lines, but constrains the interpolation to the topography, thus avoiding where there is no information, the water-table of an unconfined aquifer to be above a thalweg or other types of depression. The map is representative of the water-level condition in the weathering profile (saprolites and fractured layers), and, as established under low water condition (no recharge from rainfall), it is considered a good approximation of aquifer steady-state condition. The map was used for regionalizing hydraulic conductivity and in numerical modelling.

\subsubsection{Hydraulic conductivity data}

Few pumping test data is available in the area $(n=5$; Fig.3b) and provides local estimates of the hydraulic conductivity of the fractured layer. These hydrogeological data come from the French geological survey database (BRGM), where the basic information concerning hydraulic tests, carried out by design and technical offices, is stored. For the five cases available, tests were interpreted with the Theis model. Based on this data, hydraulic conductivity ranges between $5 \times 10^{-7}$ and $8 \times 10^{-6} \mathrm{~m} / \mathrm{s}(-6.3<\operatorname{LogK}<-5.1$, mean: -5.26$)$. These data fall in the range of the log-normal distribution of hydraulic conductivity data deduced from pumping tests of granitoïds at the scale of the Brittany region (fractured layer, Fig. 3d; mean LogK: -5.4, standard deviation: 0.8; BRGM-database, Mougin et al., 2016), suggesting that this distribution is probably not so far from that of the studied aquifer. This distribution was used as training data for regionalizing hydraulic conductivity from the gradient of the 
residual water-table elevation data (Dewandel et al., 2017b; section 3.1.). Although this distribution characterizes the average hydraulic conductivity of the fractured layer, the hydraulic conductivities of the less permeable saprolites layer are also in this range, mainly in its left part, since they are generally, in granitic areas, between $10^{-7}$ and $10^{-5} \mathrm{~m} / \mathrm{s}$ (Dewandel et al., 2006). This is why this dataset is used to regionalize the hydraulic conductivity from the water-table level of the whole weathering profile (saprolites and fractured layers). However, the numerical modelling carried out subsequently will make it possible to evaluate the bias introduced by the use of this distribution. Local data $(n=5)$ were also compared to local estimates of the produced hydraulic conductivity map.

Sixteen magnetic resonance soundings (MRS) were carried out to improve local data on hydrogeological properties (Mougin et al. 2008; Dewandel et al., 2020; Fig. 3b). MRS measurements were carried out from the ground surface with the NUMIS POLY equipment from IRIS Instruments (Bernard, 2007) with mainly 8-shape square loops for reducing noise level (Trushkin et al. 1994). Thirty-eight to fifty meter loop size and adapted number of stack ensure liable MRS signal to a maximum investigation depth of about $50 \mathrm{~m}$ with signal to noise ratio of 1.4 to 3.5. Inversion of MRS measurements were carried out with Samovar_11x64 software (Legtchenko, 2013) using a multi-layered earth model without geological constraints and automatic regularization process. Inversion results give estimates of the MRS groundwater content and MRS hydraulic conductivity as a function of depth from which the aquifer porosity and hydraulic conductivity can be deduced (Wyns et al., 2004; Vouillamoz et al., 2014). Figure 4a gives an example of the hydrogeological parameters deduced from MRS. In crystalline aquifers, Vouillamoz et al. (2014) showed that MRS porosity needs to be corrected by a factor of about 0.5 to be equivalent that deduced from pumping tests. However, they showed that the transmissivity, and the hydraulic conductivity, obtained by the MRS method was very close to that deduced from pumping tests; no correction has therefore been made to these data. From the sixteen MRS measurements, LogK values for the fractured layer vary from -5.7 to -3.7 , with an average of -4.8 (standard deviation: 0.6; Fig.4b), in the range of the previous distribution of hydraulic conductivity. These local estimates were also compared to local estimates of the hydraulic conductivity map produced. 


\subsubsection{Streamflow measurements}

At the same time as water level measurements, in August 2017, twenty-two stream flowrate measurements were performed (Fig. 3b). The measurements being carried out under the same low water conditions (no recharge by rainfall), they correspond to the discharge of groundwater into streams. They were performed with an OTT flowmeter (propeller diameter: $50 \mathrm{~mm})$. Flowrates range from $0.001 \mathrm{~m}^{3} / \mathrm{s}$ for small catchment area $\left(<1 \mathrm{~km}^{2}\right)$ to $0.13 \mathrm{~m}^{3} / \mathrm{s}$ at the outlet of the watershed $\left(57 \mathrm{~km}^{2}\right.$ in area). Plotted according to watershed area (Fig.4c), flowrate increases approximately linearly, showing that the aquifer continuously feeds the streams. As for water level measurements, flowrate values (because of low water conditions) are assumed to represent a good approximate of aquifer steady-state conditions. Combined with water-table map and catchment characteristics (i.e. length of stream, area), flow values are used for estimating basin-scale hydraulic conductivity of each sub-catchment (Dewandel et al.; 2004); see Appendix A. Values range, in LogK, between -5.7 and -4.9 , with an average of -5.3 (standard deviation: 0.25 ; Fig.4d). Values are still in the range of the distribution of hydraulic conductivity deduced from pumping tests at the scale of the Brittany region (Fig.3d). These basin-scale hydraulic conductivity values were compared with those estimated by the regionalization method, and flowrates were compared with those computed by numerical modelling.

\section{Methods}

Following Dewandel et al. (2017b) methodology, a regionalized hydraulic conductivity map was produced from which values have been compared to local estimates deduced from hydraulic tests, MRS measurements and streamflow measurements. Then, the map, a firstorder estimate of the hydraulic conductivity field, has been assessed with several hydrodynamic models (steady-state condition) to account for various ways of using the produced map, of which spatial streamflow measurements are used for validating models.

\subsection{Method for regionalizing hydraulic conductivity}

The used method has been recently proposed for evaluating the transmissivity and hydraulic conductivity fields in a crystalline aquifer (Dewandel et al., 2017b), and is briefly reminded here. It is based on the concept that large-scale variations in hydraulic head may give information on large-scale hydrodynamic properties. Where the aquifer is naturally drained (no groundwater abstraction), where vertical flow can be neglected, and where the water table 
is in pseudo-steady state and mainly controlled by topography rather than recharge (Haitjema and Mitchell-Bruker, 2005), it can be assumed that the gradient of the water-table depends on both topographic slope and aquifer horizontal transmissivity. For example, in case of relatively flat topography and where groundwater flow is horizontal, the use of continuity equation along the same flow-line for unit aquifer width (Darcy's law, $\mathrm{Q}=\mathrm{T}_{1} \operatorname{gradh}_{1}=\mathrm{T}_{2} \operatorname{gradh}_{2} \ldots ; \mathrm{T}_{\mathrm{i}}$ : transmissivity and $\operatorname{gradh}_{\mathrm{i}}$ : hydraulic head gradient of compartment i,) will give high transmissivity values where the hydraulic gradient is low and low values where the gradient is high. Therefore, where the topographic level is almost stable, the hydraulic gradient variations are, in first approximation, inversely related, to variations in aquifer transmissivity. On the other hand, in the case where the topographic variations are not negligible, it is necessary, before obtaining information on the transmissivity, to remove the influence of the topography on the water table elevation, by subtracting to it, for example, a linear water table-topography relationship. Once this trend removed, the inverse-slope of the residual water-table map is computed, and then statistically compared to local transmissivity data to produce a transmissivity field. The latter can be finally transformed into hydraulic conductivity if information on the thickness of the aquifer is available (Dewandel et al., 2017b).

Then, the best possible empirical relationship between the two statistical distributions (transmissivity [or hydraulic conductivity] measured and calculated from the gradient) is evaluated while respecting the statistical properties of the transmissivity (or hydraulic conductivity) measured. For the analysis to be meaningful, both data sets must describe the widest possible range of transmissivities that can be encountered in the studied aquifer. Finally, the calculated transmissivity (or hydraulic conductivity) is spatialized and the relevance of the map produced is evaluated on the basis of local estimates of transmissivity (or hydraulic conductivity). This is relevant because these measurements are not directly included in the mapping method (only their statistical distribution).

One of the assumptions made by the method is that vertical flow is neglected, while fractured rocks, as here, can be affected by sub-vertical fractures that allow vertical flow components. However, in such a granitic weathering profile, the hydraulic conductivity of the fractured layer, due to a denser horizontal network, is about 10 times higher horizontally than vertically (Maréchal et al. 2004; Lachassagne et al., 2021), which thus promotes horizontal flows. In addition, as the method uses a basin to sub-basin scale approach and that the aquifer thickness is small (a few ten meters) compared to the sub-basin scale ( $\mathrm{km}$ scale), then at this scale 
horizontal flows dominate (e.g. Guihéneuf et al., 2014; Kolbe et al 2016; Ayraud et al., 2008). Which is another argument to use the method here. However, when the vertical component of the flow exists and is not negligible, this can occur locally along the fault for example, the method may return falsely lower transmissivity (or hydraulic conductivity) values, but the method still delineates the shape of these areas (Dewandel et al. 2017b).

The regionalized hydraulic conductivity map of Nançon watershed is based on $i$ ) the inversegradient of the established water-table map (Fig. 3a) that was reduced from topographic effect (i.e. inverse-gradient of the reduced water-table map) divided by the aquifer thickness to make data consistent with hydraulic conductivity, and ii) the regional based statistical relationship for hydraulic conductivity (Fig. 3d). The use of this latest relationship instead of a local one, because of too little data from hydraulic tests, will be discussed later. The map was established over a grid of 500x500 m cells, and integrates hydraulic conductivity values (theoretically horizontal K) of the whole weathering profile (saprolites and fractured layers). However, since the fractured layer is the most permeable layer in the weathering profile, the map better reflects the hydraulic conductivity of this layer. Then, the map was compared to local hydraulic conductivity estimates (pumping tests [Fig. 3b], MRS measurements [Fig. 4b], and streamflow measurements [Fig. 4d]).

\subsection{Numerical modelling}

Assessment of the regionalized hydraulic conductivity map of Nançon granitic aquifer was performed by numerical modelling. Nançon hydrological model was developed using the MARTHE_7.4 CBRGM computer code (Thiéry, 2010, 2015, 2018). MARTHE allows 2D or $3 \mathrm{D}$ modelling of flows and mass transfers in aquifer systems, including climatic and human influences. Groundwater flow is computed by a 3-D finite volume approach to solve the hydrodynamic equation based on the Darcy's law and mass conservation. The model comprises a single aquifer layer that merges both saprolites and fractured layers to be consistent with the hydraulic conductivity field obtained from the regionalization method. Aquifer geometry was established from the DEM model (Fig. 1a) and the total weathering thickness map (Fig. 2b). The small Tertiary age basin located in the centre of the watershed (Landéan clays) was not considered in the modelling. The modelled domain is discretized into cells of 500x500 metres, to be consistent with other data sources. 
355

356

357

358

359

360

361

362

363

364

365

366

367

368

369

370

371

372

373

374

375

376

377

378

379

380

381

382

383

384

385

A no-flow boundary condition is applied to the watershed limits, in agreement with the established water-table map (Fig. 3a). On the other hand, groundwater overflow is allowed where the water-table surface crosscuts topographic level. For the purpose of this study, the model does not explicitly take into account the flow in the streams, avoiding thus imposed stream boundary conditions that would force the model to evacuate flow through the streams. However, the model makes possible to compute the groundwater overflow at cell-scale, i.e. the groundwater discharge to streams, which were compared to streamflow measurements (Figs. 3b, 4c). In this way, streamflow measurements were also used to assess model results. Geological faults (Figs.1a and 2) were not considered in the model as they do not influence the water-table map. (Fig 3a).

A homogeneous recharge at the basin scale was applied to the model (96 mm/year) that corresponds to the streamflow rate measured at the outlet of the watershed in August 2017 during the low flow condition (127 1/s; Fig.4c) and the groundwater abstraction at the watershed scale $(46.2 \mathrm{l} / \mathrm{s})$. In terms of groundwater abstraction, the model includes those of exploited wells (total: $18.6 \mathrm{~m}^{3} / \mathrm{h}$ or $5.2 \mathrm{l} / \mathrm{s}$ ), but not the drains in the Fougères forest, which capture some springs and sub-surface flows (total: 41 1/s). These drains represent a loss for streamflow. Computations were performed in steady state condition. Output of the models were the water balance at the watershed scale, the water-table map and the groundwater discharges to streams.

Four hydraulic conductivity field models were assessed. Model 1 used directly the hydraulic conductivity field obtained by the regionalization method (section 3.1). Model 2 assumed a uniform hydraulic conductivity value (mean value of the previous map). To go further in the analysis, investigations were performed to evaluate if zones of constant hydraulic conductivity emerged from the spatial distribution of the obtained field, the geomorphology and/or the geology. For that purpose, an automatic calibration of the hydraulic conductivity field based on head gradient method (Thiéry, 1993) has been achieved from the water-table map (Model 3). This inverted hydraulic conductivity field has been compared to the one deduced from the regionalization method. Then, the inverted field was used to identify two zones of uniform hydraulic conductivity, whose values are obtained by automatic optimization (Thiéry 1994); Model 4.

The results of the four models were analysed based on three criteria: $(i)$ the ability of the model to reproduce the groundwater flow direction at the catchment scale, (ii) the difference between the modelled water-table and that observed (i.e. Fig. 3a), and (iii) the difference 
between the modelled overflow and the streamflow measurements at the scale of subcatchments (i.e. Fig. 4c).

\section{Results}

\subsection{Regionalized hydraulic conductivity map}

Figures 5 and 6 show the results of the regionalisation method. Figure 5a displays the relationship between the elevation and the water-table level from which the reduced watertable map and its gradient are produced. Figure 5b shows the statistical distribution of the inverse-gradient of the reduced water-table divided by the aquifer thickness (1/slope/Aqui.thick. in Log scale), and Figure 5c the corresponding map (in Log scale). Figure $5 \mathrm{~d}$ presents the variogram of the map.

According to the method proposed, the best statistical relationship between the two lognormal distributions ( $\log \mathrm{K}$ from the granitoïds of Brittany, Fig. 3d, and Log[1/slope/Aqui.thick.], Fig. 5b) is K_comp. $=2.72 \times 10^{-7} \times(1 /$ slope/Aqui.thick. $)-2.9 \times 10^{-6}$, where K_comp. is the hydraulic conductivity computed. The correlation coefficient between both distributions is $\mathrm{r}^{2}$ : 0.96 (Fig. 6b). Although empirical, this relationship partly satisfies Darcy's law because it assumes a linear relationship between hydraulic conductivity and gradient. The constant, $-2.9 \times 10^{-6}$, low compared to the other parameters, reflects that some extreme values could not be taken into account (mainly extremely low gradient values) possibly due to some "errors" in water-table level interpolation. These extreme values correspond to approximately $10 \%$ of the data. This constant may also show the limit of the method for evaluating hydraulic conductivity values on singular high permeable areas and where vertical groundwater flow dominates. Nonetheless, the geometry of these areas can still be assessed.

Figure 6a shows the hydraulic conductivity map deduced from the regionalisation approach, established on a 500x500 m cell grid. The variographic analysis of LogK (computed) shows that data is moderately structured in space (nugget effect greater than 50\% of the total variance, Fig. 6c). The sill is about $3000 \mathrm{~m}$ showing that sectors of similar hydraulic conductivity cover areas of few $\mathrm{km}^{2}$. Hydraulic conductivity ranges on four orders of magnitude $\left(10^{-7}\right.$ to $\left.10^{-4} \mathrm{~m} / \mathrm{s}\right)$, with an average value at the watershed scale of about $4 \times 10^{-6} \mathrm{~m} / \mathrm{s}$. While this map does not claim to be accurate (a first-order result), it allows identifying areas more permeable than others. Overall, values are high in valleys where the water-table lies in 
the fractured layer, and low where the water-table is in the saprolites layer (mainly plateaus; Fig.2a). However, for sectors where there are no water level measurements, e.g. forest of Fougères (near NA11a and NAN04 MRS points on Fig.6a), the values have to be considered with caution.

The resulting map has been compared to local estimates of hydraulic conductivities deduced from pumping tests (5 values, see appendix Fig.B). It shows a mean absolute error of 8.0\%, i.e. an estimate of the map at \pm 0.43 in $\operatorname{LogK}$ (absolute error=Abs(LogK_comp.LogK_pump.test)/LogK_pump.test). Compared to the hydraulic conductivities estimated from MRS measurements (16 values for the fractured layer; see appendix Fig.B), the mean relative deviation is $12.5 \%$, i.e. \pm 0.64 in $\operatorname{LogK}$. In this case, calculating the relative deviation (to the mean) was preferred (relative deviation=2xAbs[logK_comp.LogK_MRS]/[LogK_comp.+LogK_MRS]), as the hydraulic conductivities deduced from MRS measurements are indirect estimates and not direct estimates as from hydraulic tests. Finally, hydraulic conductivity values estimated at sub-catchment scale from streamflow measurements were compared to the average map values of the corresponding areas $(n=22$; see appendix Fig.B). The mean relative deviation is $7.6 \%$, which corresponds to \pm 0.43 in LogK. All these comparisons show that the regionalized hydraulic conductivity map provides reliable estimates, now the objective is to test its relevance and its sensitivity through numerical modelling.

\subsection{Numerical modelling}

Figures 7 and 8 present the results of the four models in terms of modelled water-table and groundwater flow direction, location and values of overflows and scattered diagrams. Table 1 synthesizes the statistical criteria on water-table levels at watershed scale and figure 9 compares the model overflows and streamflow measurements at the sub-catchment scale.

\subsubsection{Model with the regionalized hydraulic conductivity field (Model 1)}

This model used directly the hydraulic conductivity field obtained by the regionalization method (Fig. 6a). The model closely reproduces the water-table map in terms of order of magnitude (Fig. 7a). Groundwater flow directions obtained by the model are consistent with those of the water-table map (Fig. 7a), except for a few sectors (i.e. Fougères forest), where the model does not show a drainage of the water-table by streams. However, in these sectors, as well as at the outlet of the watershed, the water-table map is not reliable due to the lack of 
water-table measurements, like the regionalized hydraulic conductivity map. Consequently, modelled water levels are largely underestimated, with differences exceeding $20 \mathrm{~m}$ and locally $30 \mathrm{~m}$ at the outlet of the watershed (Fig. 7b). This result means that the regionalization method tends to overestimate the hydraulic conductivity in those areas. Elsewhere, the differences are smaller and vary between $-14 \mathrm{~m}$ and $6.5 \mathrm{~m}$, with an average bias of $-2 \mathrm{~m}$ (bias: difference between modelled and observed water-table). This underestimation is confirmed by the scatter diagram presented in Fig. $8 \mathrm{a}$ and by the statistical criteria values (Table 1). The root mean squared error (RMSE) at the watershed scale is $7.1 \mathrm{~m}$. Nonetheless, if data from the sectors of the Fougères forest and at the outlet (i.e. 32 cells out of 243) are removed from this analysis, the RMSE obtained is $3.7 \mathrm{~m}$; which is, without any optimisation on model parameters, a good result.

Apart from the upstream zone of the Fougères forest, where the model cannot compute overflow because of too low modelled water levels, the groundwater overflowing map (Fig.7c) shows a behaviour in accordance with the aquifer functioning: the overflow occurs mainly along streams. Computed groundwater discharges to streams of the sub-catchments are compared to available streamflow measurements (Fig. 9). Overall, flows are comparable for the upstream catchments located to the North, the East and the South-West (e.g. BV1, $\mathrm{BV} 2, \mathrm{BV} 5, \mathrm{BV} 8, \mathrm{BV} 13$ and BV15). On the other hand, for the sub-catchments BV4 and $\mathrm{BV} 16$, the computed groundwater discharges to streams overestimates measured values of about 30 1/s, with repercussions for BV4 on downstream points along the stream (BV7, BV9, BV18). These differences can be explained by unknown exploited wells in these areas, but most probably because of its order of magnitude, from part of the groundwater flow collected by the drains located in the forest of Fougères (drains being not considered in the model) that cannot reach the streams (total abstraction of drains: 41 1/s), some upstream parts of these subcatchments taking place in this forest. Therefore, the flow measurements in these areas are most likely reduced from the abstraction of drains.

\subsubsection{Model with a uniform hydraulic conductivity value (Model 2)}

In order to assess the benefit of the hydraulic conductivity field proposed by the regionalization method, this second model uses a uniform hydraulic conductivity value at the watershed scale, which is the average value of regionalized field $\left(3.9 \times 10^{-6} \mathrm{~m} / \mathrm{s}\right)$. Figure $7 \mathrm{e}$ shows that the water-level deviation is $+/-3 \mathrm{~m}$ on the valleys, but the water-table is largely underestimated on the plateaus and some dry valleys $(>15-20 \mathrm{~m})$. The trends are similar to Model 1, however, according to the statistical criteria established for the two models (Table 
1), the results obtained using the regionalized hydraulic conductivity field are better in terms of bias, RMSE, etc. Results on overflows are similar to the one of the Model 1 (Fig.9).

\subsubsection{Model with two zones of uniform hydraulic conductivity values (Models 3 and 4)}

\section{Inversion of the hydraulic conductivity field (Model 3)}

Using Marthe's code (Thiéry, 1993), an automatic inversion of the hydraulic conductivity field was performed from the observed water-table map (Fig. 3a), by constraining the model with the extreme hydraulic conductivity values obtained by the regionalization method (min: $6 \times 10^{-8} \mathrm{~m} / \mathrm{s}$, max: $\left.7 \times 10^{-5} \mathrm{~m} / \mathrm{s}\right)$. The inversion method is based on hydraulic head gradients approach and consists in adjusting in each cell of the model the value of the hydraulic conductivity to reduce the error between the computed head and the measured one. As an initial value for the inversion, the hydraulic conductivity is assumed uniform over the entire domain and corresponds to the mean value tested in Model $2\left(\mathrm{~K}: 3.9 \times 10^{-6} \mathrm{~m} / \mathrm{s}\right)$.

Figures 10a and $\mathrm{b}$ show the hydraulic conductivity field obtained by inverse modelling and their statistical distribution (in $\log K$ ). The distribution of the inverted field is fairly homogeneous with more than $95 \%$ of values between $6 \times 10^{-6} \mathrm{~m} / \mathrm{s}$ and $6 \times 10^{-7} \mathrm{~m} / \mathrm{s}$. The minimum value is $2 \times 10^{-7} \mathrm{~m} / \mathrm{s}$, maximum $1.8 \times 10^{-5} \mathrm{~m} / \mathrm{s}$ and the average $1.4 \times 10^{-6} \mathrm{~m} / \mathrm{s}$, which is lower than that of the regionalized field $\left(3.9 \times 10^{-6} \mathrm{~m} / \mathrm{s}\right) .65 \%$ of the values are in the range $\left[1.2 \times 10^{-6}-3.3 \times 10^{-6} \mathrm{~m} / \mathrm{s}\right]$ and $30 \%$ in the range $\left[3 \times 10^{-7}-8 \times 10^{-7} \mathrm{~m} / \mathrm{s}\right]$, and are, overall, higher on the valleys than on the plateaus as previously observed (Fig.1a). The comparison between this map and the one from the regionalization method is discussed later.

The statistical criteria established for this model are naturally good (Fig. 8c; Table 1). The bias and the RMSE on water-table are $0.7 \mathrm{~m}$ and $1.7 \mathrm{~m}$ respectively. The computed groundwater discharges to streams of the water table of sub-catchments are compared to local measurements (Fig. 9). Values are comparable for many sub-basins (e.g. BV1, BV2, BV5, BV8, BV13 and BV15). For BV4, a significant flow difference is still observed (29 1/s), which also affects downstream points (BV7, BV9, BV18). The possible explanations of these differences are those given above.

\section{Model with two zones of uniform hydraulic conductivity (Model 4)}

Based on the distribution of the inverted field (Fig. 10b), two zones of uniform hydraulic conductivity were defined (zone 1 and zone 2, Fig. 10c). Zone 1 generally corresponds to the valleys where the fractured layer outcrops and zone 2 coincides with the upstream part of sub- 
catchments and plateaus as well as zones with a significant thickness of saprolites, excepted in the Fougères forest. Note that this zoning between the most permeable areas on the valleys and the least permeable on the plateaus was already visible on the hydraulic conductivity map resulting from the regionalization method (Fig. 6a).

Finally, an automatic optimization of the hydraulic conductivity values of the two zones was carried out with Marthe's code. This optimization was constrained by the following hydraulic conductivity values, for zone $1\left[10^{-6} \mathrm{~m} / \mathrm{s}-2 \times 10^{-5} \mathrm{~m} / \mathrm{s}\right]$ and for zone $2\left[10^{-8} \mathrm{~m} / \mathrm{s}-9 \times 10^{-7} \mathrm{~m} / \mathrm{s}\right]$. Resulting uniform hydraulic conductivities are $2.1 \times 10^{-6} \mathrm{~m} / \mathrm{s}$ for zone 1 and $3.3 \times 10^{-7} \mathrm{~m} / \mathrm{s}$ for zone 2, therefore higher where the water table is located in the fractured layer, and lower where it is in the saprolites.

The scatter diagram (Fig. 8d) shows that the model reproduces the observed water table well with very satisfactory statistical criteria (Table 1). At the watershed scale, the bias is $0.67 \mathrm{~m}$ and the RSME is $1.8 \mathrm{~m}$, thus very close to the model using the inverted hydraulic conductivity field (Model 3).

Results on groundwater discharges to streams at sub-catchment scale are similar to the previous models (Fig. 9).

\section{Discussion}

\subsection{Regionalized hydraulic conductivity}

Despite the restrictive hypotheses assumed in the regionalization method (vertical flow neglected, absence of pumping wells, water table in pseudo-steady state and controlled by topography) the resulting regionalized hydraulic conductivity field on the Nançon watershed shows consistent results compared to other available data sources: pumping tests, estimates from MRS measurements and from streamflows at sub-catchment scale. It also appears that the hypothesis, which neglects the vertical flow did not introduce a significant bias at the watershed scale. This is mainly due to the thinness of the aquifer compared to the groundwater flow lines at the watershed scale, which limits vertical flow components at this scale (Guihéneuf et al., 2014; Kolbe et al 2016; Ayraud et al., 2008).

The comparisons with local hydraulic conductivity estimates show also that despite the lack of local available hydraulic data for evaluating a clear distribution of hydraulic conductivity at the watershed scale, the use of the training distribution from the granitoïds of Brittany 
provides a satisfactory result, although defined for the fractured layer only. In addition, the map also shows good consistency with the MRS estimates, which confirms previous works (Vouillamoz et al., 2014). Hydraulic conductivity ranges on four orders of magnitude $\left(10^{-7}\right.$ to $10^{-4} \mathrm{~m} / \mathrm{s}$; average: $3.9 \times 10^{-6} \mathrm{~m} / \mathrm{s}$ ), which is consistent to other works performed on granitic aquifers (e.g. Maréchal et al., 2004; Dewandel et al., 2012). Furthermore, it confirms that where granitic rocks are exposed to deep weathering processes, aquifers are characterized by similar ranges of hydrogeological properties (Dewandel et al., 2006; Lachassagne et al., 2011, 2021), which facilitates, and justifies, the use of training data in the absence of sufficient local data, as it was done here. Although the method does not claim to be perfectly accurate, the produced map, a first-order result, describes the spatial heterogeneity and shows that sectors of similar hydraulic conductivity cover areas of the order of few $\mathrm{km}^{2}$. As indicated previously, a certain consistency is found with the geological information as, on the whole, the values are the highest where the water-table lies in the fractured layer (mainly valleys), and the lowest in areas where the water-table is the saprolites layer (mainly plateaus).

Figure 11 compares the field obtained from the inverse modelling (Model 3) to that proposed by the regionalization method. The average relative deviation is $2.5 \%$ with a mean deviation less than or equal to $5 \%$ over $93 \%$ of the whole area, which corresponds to $\log \mathrm{K} \pm 0.29$. This shows that the regionalization method made it possible to propose a spatial pattern of the hydraulic conductivity field relatively close to that obtained by the inverse modelling. In addition, Figure 11a illustrates that as soon as the density of water-table measurements is sufficient, the method provides relatively robust estimates (deviation of less than $3.5 \%$ over $75 \%$ of the basin, i.e. $\operatorname{LogK} \pm 0.20$ ). However, where the density of field data decreases (e.g. Fougères forest, outlet of the watershed), the estimates of the regionalized hydraulic conductivity map, but also the map resulting from the inverse modelling, logically become more erroneous. This point on data density is addressed below through an experiment performed on the Maudouve-Noë Sèche watershed.

\subsection{Modelling}

The suitability of the four sets of hydraulic conductivity field was assessed, the regionalized field (Model 1), an uniform field (Model 2, average value of the previous model), the one deduced from inverse modelling (Model 3), and the last with two zones of uniform hydraulic conductivity (Model 4), defined from the previous one. 
Overall, and depending on the models, the observed water table is more or less well reproduced with uncertainties in the Fougères forest and at the outlet of the basin due to the lack of field data. The simulated groundwater discharges to streams are comparable to measurements made in many sub-catchments. However, the models generally overestimate the stream flows in some places. This can be explained, one the one hand, by a lack of knowledge about the pumping wells (influence possibly underestimated), but most likely, on the second hand, by the drains in the Fougères forest (not considered in models) capturing part of the groundwater that can no longer return to streams (total abstraction from drains: 41 $1 / \mathrm{s})$.

The model using the regionalized field directly (Model 1) reproduces rather well the watertable map and the groundwater flow directions (except in the Fougères forest due to the lack of data). Considering all the assumptions involved in the regionalization method, this is already a good result. However, modelled water-table levels are in average underestimated, which can be explained by the use of the training distribution (hydraulic conductivity database from granitoids of Brittany) and not from values of the studied watershed. It is therefore possible that the mean of this latter distribution may be greater than that of the Nançon watershed, what is ultimately suggested by the fields resulting from the numerical inversion and optimization of Models 3 and 4 (K_average, Model 1: $3.9 \times 10^{-6} \mathrm{~m} / \mathrm{s}$, Model 3: $1.4 \times 10^{-6}$ $\mathrm{m} / \mathrm{s}$, Model 4: $1.3 \times 10^{-6} \mathrm{~m} / \mathrm{s}$ ). This difference can also be explained by the use of a training distribution defined for the fractured layer while the regionalized map is deduced from information on the entire weathering profile, thus integrating the less permeable saprolites layer.

The model using an average value of hydraulic conductivity at the watershed scale (Model 2) shows similar trends to the model 1 (underestimation of the water-table), although its statistical criteria are less good. Note that this model is derived from the regionalized model, and if the average hydraulic conductivity of the pumping tests had been used, the water table would have been even more underestimated (average of 5 data: $5.5 \times 10^{-6} \mathrm{~m} / \mathrm{s}$ ). The relative success of this model is probably explained by the spatial distribution of the hydraulic conductivity that is characterized by set of small areas (few $\mathrm{km}^{2}$ ) with homogeneous values. This leads to a relatively randomized and homogeneous pattern of the hydraulic conductivity field at the watershed scale, which explains the constant increase of flow (groundwater flow) along streams (Fig. 4c). This underlines the relatively homogenous character of such aquifers at the scale of watersheds of a few ten $\mathrm{km}^{2}$, allowing approximating them by a porous 
613

614

615

616

617

618

619

620

621

622

623

624

625

626

627

628

629

630

631

632

633

634

635

636

637

638

639

640

641

642

643

medium and thus prescribing uniform hydraulic conductivity values to each layers or compartments to provide reliable estimates of the water-table and flow distribution (Join et al., 2005; Rivard et al., 2008; Leray et al., 2013; Kolbe et al., 2016; Marçais et al.; 2017; Durand et al., 2017; McLaren et al., 2012; Dickson et al., 2018...).

For models 3 and 4, the regionalized field was used to constrain the inverted hydraulic conductivity fields. The model with two zones of uniform hydraulic conductivity (Model 4) was based on the distribution of hydraulic conductivity deduced from the inverse modelling of the water-table map (Model 3). Nonetheless, these areas, or at least areas of similar shapes, could have been defined directly from the regionalized hydraulic conductivity map (more permeable in valleys and mainly the low permeable on plateaus). The use of this two-zone field, the hydraulic conductivity of which is obtained by an automatic optimization method, has led to very satisfactory results (RMSE: $1.8 \mathrm{~m}$ ), very close to that of the inverted field at the watershed scale (Model 3). This result is explained, as for the results of model 2, by the relative homogeneity of the aquifer layers properties at the $\mathrm{km}$ scale. Model 3 confirms that, as expected, the mean hydraulic conductivity of the aquifer is higher where the water table is located in the fractured zone ( valleys), and lower where it is located in the saprolites ( plateaus). This result is very encouraging and opens prospects for using qualitative information to constrain the spatialization of hydrodynamic parameters. Therefore, the combined use of the regionalization method - for defining zones and hydraulic conductivity ranges, and the numerical inversion made it possible to reduce the uncertainties of the hydraulic conductivity field.

\subsection{Application on areas with much less field data}

In order to test the sensitivity of our approach on areas with a lesser amount of data, similar experiments were carried out on the Maudouve-Noë Sèche watershed (Brittany region, Côte d'Armor Dept., France, Fig. 1b). Similarly to the Nançon area, a regionalized hydraulic conductivity map was produced and assessed through numerical modelling. Here, only the regionalized field (similar to the Model 1 in Nançon) has been evaluated with the objective of assessing whether with less data on the water table, it is possible to produce realistic results. Only the main results are presented here, more information is provided as Supporting Information. 
The area corresponds to two contiguous catchments, the Maudouve $\left(30 \mathrm{~km}^{2}\right)$ and the Noë Sèche $\left(10 \mathrm{~km}^{2}\right)$. The geological context of the area is more contrasted compared to that of the Nançon basin, and consists of granitoïds of various types (mainly granites and migmatites). Rocks are also deeply weathered, but the saprolites layer has been largely eroded (thickness: a few metres to ten metres) and the underlying fractured layer is on average $40 \mathrm{~m}$ thick.

A water-table map was drawn, for August 2018, using the same technic as described above, but using measurements on 33 abandoned wells only (Fig. 12a). Water levels are shallow, at $0.7 \mathrm{~m}$ below ground level on average, more or less parallel to the topographic surface. Based on this map and the hydraulic conductivity distribution of granitoïds of Brittany (Fig. 3d), a regionalized hydraulic conductivity map was built (Fig. 12b). Map values cover four orders of magnitude $\left(10^{-7}\right.$ to $\left.10^{-4} \mathrm{~m} / \mathrm{s}\right)$ with an average value at the watershed scale of $2.8 \times 10^{-6} \mathrm{~m} / \mathrm{s}$, close to the one evaluated for the Nançon area. Its comparison to the few available local estimates shows relatively consistent results: from pumping tests (mean absolute error: 16.9\%, $\operatorname{LogK} \pm 0.83, \mathrm{n}=3$ but all located in the same area), from MRS measurements (mean relative deviation: $4.5 \%, \operatorname{LogK} \pm 0.25, \mathrm{n}=7$ available within the watershed) and from streamflow measurements (mean relative deviation: $6.1 \%, \operatorname{LogK} \pm 0.33, \mathrm{n}=8$ ).

Similarly to the Nançon area, the numerical model considers the topography, the geometry of the weathering profile and the abstraction of exploited wells (total: $8.5 \mathrm{~m}^{3} / \mathrm{h}$ or $2.4 \mathrm{l} / \mathrm{s}$ ). Model boundary conditions are: no-flow boundary at the watershed limits and homogeneous recharge at the scale of each watershed (Noë Sèche: $160 \mathrm{~mm}$ and Maudouve: $120 \mathrm{~mm}$, with respect to the streamflow rates measured at the outlets of watersheds and groundwater abstraction). Computations were performed on a 500x500 m cell grid, and model results were analysed based on the same criteria as before.

Figures $12 \mathrm{c}$ and $\mathrm{d}$ presents the results of this modelling. The modelled water-table map reproduces fairly well the observed map (Fig. $12 \mathrm{~d}$; bias: $-2.9 \mathrm{~m}$; RMSE: $6.5 \mathrm{~m}$ ), and computed groundwater discharges to streams are consistent with streamflow measurements (Fig. 12 c), excepted at the outlet of the Maudouve watershed, where the record at the gauging station is possibly underestimated (no field discharge measurement was performed there). These results confirm that the use of the regionalized hydraulic conductivity map gives satisfactory results despite a density of water-table data $\left(0.8 \mathrm{pts} / \mathrm{km}^{2}\right)$ two times lower compared to Nançon watershed $\left(1.74 \mathrm{pts} / \mathrm{km}^{2}\right)$. However, as for the Nançon area, the regionalization method tends to overestimate the hydraulic conductivity values (modelled water-table lower than measured, Fig. 12d), probably because of the hydraulic conductivity 
distribution used (Brittany; Fig. 3d) defined for the fractured layer while the regionalized map is deduced from information on the entire weathering profile. Finally, the presented results show that with a density of water-table measurements of about 1 measurement per $\mathrm{km}^{2}$ and few streamflow measurements (during low water conditions) it is possible to obtain a relatively robust first-order assessment of the hydraulic conductivity field.

\section{Conclusion}

Modelling of groundwater resources in crystalline aquifers is often difficult mainly because of the strong spatial heterogeneity of aquifer parameters. The evaluation of the regionalized hydraulic conductivity maps with numerical models (in steady-state condition) made it possible to report their relevance and to test the sensitivity of the approach carried out on two granitic watersheds in Brittany (Nançon watershed, $57 \mathrm{~km}^{2}$, and Maudouve-Noë Sèche, 40 $\left.\mathrm{km}^{2}\right)$.

On Nançon watershed, the model using directly the regionalized field (model 1) reproduces rather well the water-table map and the groundwater flow directions (except in the Fougères forest due to the lack of data). RMSE on the water-table levels is $7.1 \mathrm{~m}$ over the entire domain, but decreases to $3.7 \mathrm{~m}$ when sectors where no water-level measurements are excluded. However, simulated water-table levels are in average underestimated. This can be explained by the use of a training distribution (hydraulic conductivity database from granitoids of Brittany), and not one established from values obtained on the studied watershed, but also because this distribution is defined for the fractured layer while the regionalized map is deduced from the information on the entire weathering profile (both saprolites and fractured layers). Consequently, the regionalized field moderately overestimates the average aquifer hydraulic conductivity $\left(3.9 \times 10^{-6}\right.$ instead of $\left.1.4 \times 10^{-6} \mathrm{~m} / \mathrm{s}\right)$. The comparison between the field obtained from the inverse modelling (Model 3) and that proposed by the regionalization method (Model 1) shows that both fields are close in terms of mean values and spatial distribution (mean deviation between the two fields is $2.5 \%$, LogK $\pm 0.14)$. This highlights that as soon as sufficient information is available on the water table, it is possible to propose a relatively robust hydraulic conductivity map at the watershed scale. The model 2 (uniform field) shows similar trends, but statistical criteria are significantly less good particularly on plateau areas. Finally, the model 4, a 2-zone hydraulic conductivity field, has led to satisfactory results (RMSE: $1.8 \mathrm{~m}$ ), which underlines, as Model 2, the relatively 
homogenous character of such aquifers at a $\mathrm{km}$ scale. This model (Model 3) shows that the hydraulic conductivity of the aquifer is higher $\left(2.1 \times 10^{-6} \mathrm{~m} / \mathrm{s}\right)$ where the water table is located in the fractured zone ( valleys) and lower $\left(3.3 \times 10^{-7} \mathrm{~m} / \mathrm{s}\right)$ where it is located in the saprolites ( plateaus); what is ultimately expected. In all models, the computed groundwater discharges to streams of the water table are comparable to the streamflows measured in most subcatchments. However, the models overestimate them in certain places, which can be due to the lack of knowledge on pumping wells, but mainly to the drains in the forest of Fougères that capture part of the groundwater flow, which can no longer return to the streams.

For the Maudouve-Noë Sèche watershed, the modelled water-table map (based on the regionalized field) reproduce fairly well the observed map (bias: -2.9 m; RMSE: $6.5 \mathrm{~m}$ ), and computed groundwater overflows are, overall, consistent with streamflow measurements.

The regionalization method makes it possible to produce a first-order assessment of the hydraulic conductivity field, which shows a good consistency with local hydraulic conductivity estimates, is able to describe zones with high and low values, and when used in a numerical model reproduces rather well the water-table map, the groundwater flow directions and groundwater discharges to streams. Even if one can doubt the reality of the estimated value at a given point, the regionalized field can be taken as an advantage for carrying out a relatively robust modelling with the creation of zones of different hydraulic conductivity, from ranges of values given by the map (e.g. Model 4 on Nançon watershed). The other advantage of the regionalization method is that, unlike the inversion of the hydraulic conductivity field by mathematical models, it is not necessary to prescribe a recharge or other boundary conditions, conditions often difficult to estimate, or even geometry of aquifers (in this case only a regionalization of aquifer transmissivity is possible). Thus, many conditions that can influence the hydraulic conductivity field obtained from the inversion. The joint use of the regionalization method and the numerical inversion therefore makes it possible to reduce the uncertainties of models.

To go further, it would be interesting to test these approaches on other watersheds and in particular larger watersheds, of the order of $1000 \mathrm{~km}^{2}$ or more. Then arises the question to define the density of the measurements required in terms, for example, of water-table measurements or number of hydraulic tests to reasonably use the method. For the MaudouveNoë Sèche watershed, the density of water-table measurements for establishing the regionalized field was around half $\left(0.8 \mathrm{pt} / \mathrm{km}^{2}\right)$ the one of Nançon area $\left(1.74 \mathrm{pt} / \mathrm{km}^{2}\right)$, the results are naturally less precise, but already give an idea of the distribution of hydraulic 
742 conductivities at the watershed scale. This is an essential point on which future works must

743 focus. Another point will concern areas with a highly contrasted hydraulic conductivity field 744 or within complex aquifer systems, i.e. with zones characterized by very contrasted 745 properties, and even in depth. The regionalization method should be repeated for each area, or 746 depth interval, provided that the hydraulic conductivity distributions of each zone. Here, one747 layer model has been used for reproducing the water-table map, efforts should be made in the 748 future to generate 3-D hydraulic conductivity field, which will allow to integrate the 3-D 749 structures of these aquifers (i.e. saprolites and fractured layers), and thus improve of our 750 models.

751

\section{Acknowledgments}

753 The authors are grateful for a research-sponsorship from BRGM (France) and from the 754 MORPHEUS Research Project co-funded by the French Water Agency of Loire-Brittany 755 (AELB). The authors thank both reviewers of the journal for their fruitful comments and 756 remarks. The authors also thank F. Robustelli and J. Thiéphaine, students at Géosciences 757 Rennes, for their help in acquiring field data. 
759

760

761

762

763

764

765

766

767

768

769

770

771

772

773

774

775

776

777

778

779

780

781

782

783

784

785

786

787

788

\section{References}

Ahmed, S., Sreedevi, P.D., 2008. Simulation of flow in weathered-fractured aquifer in a semiarid and over-exploited region. Groundwater Dynamics in Hard Rock Aquifers. Springer, pp. 219-233. https://doi.org/10.1007/978-1-4020-6540-8_219.

Ayraud, V., Aquilina, L., Labasque, T., Pauwels, H., Molenat, J., Pierson-Wickmann, A.-C., Durand, V., Bour, O., Tarits, C., Le Corre, P., Fourre, E., Merot, P., Davy, P., 2008. Compartmentalization of physical and chemical properties in hard-rock aquifers deduced from chemical and groundwater age analyses. Applied Geochemistry 23, 2686-2707. https://doi.org/10.1016/j.apgeochem.2008.06.001.

Bianchi, MacDonald A.M., Macdonald D.M.J., Asare E.B., 2020. Investigating the productivity and sustainability of weathered basement aquifers in tropical Africa using numerical simulation and global sensitivity analysis. Water Resources Research, 10.1029/2020WR027746.

Bernard, J., 2007. Instruments and field work to measure a magnetic resonance sounding. Bol. Geol. Min. 118, 459-472.

Boisson, A., N. Guiheneuf, J. Perrin, O. Bour, B. Dewandel, A. Dausse, M. Viossanges, S. Ahmed and J.C. Marechal, 2015. Determining the vertical evolution of hydrodynamic parameters in weathered and fractured South Indian crystalline-rock aquifers: insights from a study on an instrumented site, Hydrogeology Journal, DOI 10.1007/s10040-014-1226-x.

Boutt, D.F., Diggins, P., Mabee, S., 2010. A field study (Massachusetts, USA) of the factors controlling the depth of groundwater flow systems in crystalline fractured-rock terrain. Hydrogeology Journal 18, 1839-1854. https://doi.org/10.1007/s10040-010-0640-y

Carrera, J., Neuman, S. P., 1986. Estimation of aquifer parameters under transient and steady state conditions: 1. Maximum likelihood method incorporating prior information, Water Resour. Res., 22, 199-210.

Carrera J., Alcolea A., Medina A., Hidalgo J. and Slooten L.J., 2005. Inverse problem in hydrogeology. Hydrogeol Journal, 13, 206-222.

Chandra S., Ahmed S., Ram A. and Dewandel B., 2008. Estimation of hard rock aquifers hydraulic conductivity from geoelectrical measurements: A theoretical development with field application. J. of Hydrology, 357, 218-227. 
789

790

791

792

793

794

795

796

797

798

799

800

801

802

803

804

805

806

807

808

809

810

811

812

813

814

815

816

817

818

Courtois N., Lachassagne P., Wyns R., Blanchin R., Bougaïré,F.D., Somé S. and Tapsoba A., 2010. Large-scale mapping of hard-rock aquifer properties applied to Burkina Faso, Ground Water, 48 (2), 269-283.

Darko, Ph.K. and Krásný J., 2007. Regional transmissivity distribution and groundwater potential in hard rock of Ghana. In: Krásný J. \& Sharp J.M. (eds.): Groundwater in fractured rocks, IAH Selected Papers, 9, 1-30. Taylor and Francis.

Dhakate, R., Singh, V.S., Negi, B.C., Chandra, S., Ananda, Rao.V., 2008. Geomorphological and geophysical approach for locating favourable groundwater zones in granitic terrain, Andhra radish, India. J. Environ. Manage. 88, 1373-1383.

de Marsily G., Delay F., Gonçalvès J., Renard Ph., Teles V. and Violette S., 2005. Dealing with spatial heterogeneity. Hydrogeology Journal, 13, 161-183.

Dewandel B., Lachassagne P., Qatan A., 2004. Spatial measurements of stream baseflow, a relevant method for aquifer characterization and permeability evaluation. Application to a hard rock aquifer, the Oman ophiolite, Hydrol. Processes 18, 3391-3400.

Dewandel B., Lachassagne P., Wyns R., Maréchal J.C. and Krishnamurthy N.S., 2006. A generalized hydrogeological conceptual model of granite aquifers controlled by single or multiphase weathering. J. of Hydrology, 330, 260-284, doi:10.1016/j.jhydrol.2006.03.026.

Dewandel, B., Perrin, J., Ahmed, S., Aulong, S., Hrkal, Z., Lachassagne, P., Samad, M., Massuel, S., 2010. Development of a tool for managing groundwater resources in semi-arid hard rock regions. Application to a rural watershed in South India. Hydrol. Process. 24, 2784 2797.

Dewandel, B., Maréchal, J.C., Bour, O., Ladouche, B., Ahmed, S., Chandra, S., Pauwels, H., 2012. Upscaling and regionalizing hydraulic conductivity and effective porosity at watershed scale in deeply weathered crystalline aquifers. Journal of Hydrology, 416-417, 83-97. doi:10.1016/j.jhydrol.2011.11.038.

Dewandel B., Alazard M., Lachassagne P., Bailly-Comte V., Couëffé R., Grataloup S., Ladouche B., Lanini S., Maréchal J.-C., Wyns R., 2017a. Respective roles of the weathering profile and the tectonic fractures in the structure and functioning of crystalline thermo-mineral $\begin{array}{lllll}\text { carbo-gaseous } & \text { aquifers. } & \text { J. } & \text { Hydrol., } & \text { 547, }\end{array}$ http://dx.doi.org/10.1016/j.jhydrol.2017.02.028. 
Dewandel B., Jeanpert J., Ladouche B., Join J.-L., Maréchal J.-C., 2017b. Inferring the heterogeneity, transmissivity and hydraulic conductivity of crystalline aquifers from a detailed water-table map. J. Hydrol., 550, 118-129. http://dx.doi.org/10.1016/j.jhydrol.2017.03.075.

Dewandel B., Caballero Y., Perrin J., Boisson A., Dazin F., Ferrant S., Chandra S., Maréchal J.-C., 2017c. A methodology for regionalizing 3- D effective porosity at watershed scale in crystalline aquifers. Hydrological Processes;1-19. doi:10.1002/hyp.11187.

Dewandel B., Amraoui N., Baltassat J.M., Boisson A., Caballero Y., Mougin B., 2020. Research project MORPHEUS: methodology for regionalizing hydrogeological properties in crystalline aquifers (in French). Final report BRGM/RP 69431-FR, p. 131.

Dickson, N.E.M., Comte, J.C., Koussoube, Y., Ofterdinger, U., Vouillamoz, J.M. (2018). Analysis and numerical modelling of large-scale controls on aquifer structure and hydrogeological properties in the African basement (Benin, West Africa). Geological Society, London, Special Publications. From: OFTERDINGER, U., MACDONALD, A. M., COMTE, J.-C. \& YOUNG, M. E. (eds) Groundwater in Fractured Bedrock Environments. Geological Society, London, Special Publications, 479, https://doi.org/10.1144/SP479.2

Durand V., Léonardi V., de Marsily G., Lachassagne P., 2017. Quantification of the specific yield in a two-layer hard-rock aquifer model. J. of Hydrology, 557, 328-339. http://dx.doi.org/10.1016/i.jhydrol.2017.05.013

Haitjema, H.M., Mitchell-Bruker, S., 2005. Are water tables a subdued replica of the topography? Ground Water, 43, 781-786. doi: 10.1111/j.1745-6584.2005.00090.x

Hsieh P.A. 1998. Scale effects in fluid flow through fractured geological media, in Scale Dependence and Scale Invariance in Hydrology, ed. G. Sposito, 335-353, Cambridge Univ. Press, Cambridge, U. K.

Goderniaux, P., Davy, P., Bresciani, E., de Dreuzy, J.-R., Le Borgne, T., 2013. Partitioning a regional groundwater flow system into shallow local and deep regional flow compartments. Water Resources Research, 49(4): 2274-2286. 10.1002/wrcr.20186

Guihéneuf, N., Boisson, A., Bour O., Dewandel, B., Perrin, J., Dausse, A., Viossanges, M., Chandra, S., Ahmed, S., Maréchal, J.C., 2014. Groundwater flows in weathered crystalline rocks: impact of piezometric variations and depth-dependent fracture connectivity. J Hydrol $511: 320-334$. 
Haitjema, H.M., Mitchell-Bruker, S., 2005. Are water tables a subdued replica of the topography? Ground Water, 43, 781-786. doi: 10.1111/j.1745-6584.2005.00090.x

Illman, W.A., 2014. Hydraulic tomography offers improved imaging of heterogeneity in fractured rocks. Groundwater, Vol. 52, No. 5, Sept.-Oct., p. 659-684.

Join, J.L., Robineau, B., Ambrosi, J.P., Costis, C., Colin, F., 2005. Groundwater in ultramafic mined massifs of New Caledonia. C. R. Geosci. 337, 1500-1508.

Kolbe T., Marçais J., Thomas Z., Abbott B.W., de Dreuzy J.-R., Rousseau-Gueutin P., Aquilina L., Labasque T., Pinay G., 2016. Coupling 3D groundwater modeling with CFCbased age dating to classify local groundwater circulation in an unconfined crystalline aquifer J. of Hydrology, 543, 31-46. . http://dx.doi.org/10.1016/j.jhydrol.2016.05.020

Krásný, J., 1993. Classification of transmissivity magnitude ad variation. Ground Water, 31(2), 230-236.

Krásný, J., 2000. Geologic factors influencing spatial distribution of hard rock transmissivity. Sililo O et al (eds): Groundwater : Past Achievements and Future Challenges. Proc. 30 IAH Congress, 2000, 187-191, Cape Town, Balkema, Rotterdam.

Lachassagne P., Wyns R., Bérard P., Bruel T., Chéry L., Coutand T., Desprats J.F., and Le Strat P., 2001. Exploitation of high-yield in hard-rock aquifers: Downscaling methodology combining GIS and multicriteria analysis to delineate field prospecting zones. Ground Water, 39 (4), 568-581.

Lachassagne, P. Wyns, R., Dewandel, B., 2011. The fracture permeability of hard rock aquifers is due neither to tectonics, nor to unloading, but to weathering processes. Terra Nova, Vol 23, No. 3, 145-161. doi: 10.1111/j.1365-3121.2011.00998.x

Lachassagne, P. Wyns, R., Dewandel, B., 2021. Review: Hydrogeology of weathered crystalline/hard-rock aquifers_-guidelines for the operational survey and management of their groundwater resources. Hydrogeol. Journ., https://doi.org/10.1007/s10040-021-02339-7.

Le Borgne T., Bour O., de Dreuzy J.R., Davy P. and Touchard F., 2004. Equivalent mean flow models for fractured aquifers: insights from a pumping tests scaling interpretation. Water Resour. Res., 40, W03512, 1-12. 
877 Le Borgne T., Bour O., Paillet F.L and Caudal J.P., 2006. Assessment of preferential flow 878 path connectivity and hydraulic properties at single-borehole and cross-borehole scales in 879 fractured aquifer. J. of Hydrology, 328, 347-359.

880 Legtchenko A., 2013. Magnetic resonance imaging for groundwater, Wiley-ISTE, 158 pp., 881 doi:10.1002/9781118649459.

882 Leray S., de Dreuzy J.-R., Bour O., Bresciani E., 2013. Numerical modeling of the 883 productivity of vertical to shallowly dipping fractured zones in crystalline rocks. J. of 884 Hydrology, 481, 64-75. http://dx.doi.org/10.1016/j.jhydrol.2012.12.014

885 Lubczynski M.W., Gurwin J., 2005. Integration of various data sources for transient 886 groundwater modeling with spatio-temporally variable fluxes - Sardon study case, Spain. J. of 887 Hydrology, 306, 71-96. doi:10.1016/j.jhydrol.2004.08.038.

Paillet F.L., 1998. Flow modelling and permeability estimations using borehole flow logs in 889 heterogeneous fractured formation. Water Resour. Res., 34 (5), 997-1010.

890 McLaren, R., E. A. Sudicky, Y.-J. Park, and W. A. Illman (2012), Numerical simulation of 891 DNAPL emissions and remediation in a fractured dolomitic aquifer, Journal of Contaminant 892 Hydrology, 136-137, 56-71.

893 894 895 896 897 898

Madrucci V., Taioli F., de Araujo C.C., 2008. Groundwater favourability map using GIS multicriteria data analysis on crystalline terrain, Sao Paulo State, Brazil. J. Hydrol., 357, 153173.

Marçais, J., De Dreuzy J.-R., Erhel J., 2017. Dynamic coupling of subsurface and seepage flows solved within a regularized partition formulation. ADWR, 109: 94 - 105 . https://doi.org/10.1016/j.advwatres.2017.09.008

Maréchal J.C., Dewandel B., and Subrahmanyam K., 2004. Contribution of hydraulic tests at different scales to characterize fracture network properties in the weathered-fissured layer of a hard rock aquifers. Water Resourc. Res.,40, W11508.

Mizan S.A., Dewandel B., Selles A., Ahmed S., Caballero Y. 2019. A simple groundwater balance tool to evaluate the three-dimensional specific yield and the two-dimensional recharge: application to a deeply weathered crystalline aquifer in southern India. Hydrogeology Journal, https://DOI.ORG/10.1007/S10040-019-02026-8 
906

907

908

909

910

911

912

913

914

915

916

917

918

919

920

921

922

923

924

925

926

927

928

929

930

931

932

933

934

935

Mougin, B., Baltassat, J-M., Blanchin, R., Putot, E., Schroëtter, J-M., Wyns, R., 2008. Project SILURES watersheds Ille-et-Vilaine, Nançon catchment (In French), Final report year 2 BRGM/RP-56318-FR. 82. P. +appendices.

Mougin B., Lucassou F., Husson F., Schroëtter J-M., Morel O., Guillemain L., Winckel A., Koch F., Crenner M., Naud E., Reuzé C., Priou M., 2016. SIGES Brittany phase 2 (Information System for Groundwater Management) - Improvement of existing content and development of additional contents (In French). Final report BRGM/RP-65483-FR.

Razack M. and Lasm T., 2006. Geostatistical estimation of the transmissivity in a highly fractured metamorphic and crystalline aquifer (Man-Danane Region, Western Ivory Coast). J. of Hydrology, 325, 164-178.

Rivard C., Michaud Y., Lefebvre R. Deblonde C., Rivera A., 2008. Characterization of a regional aquifer system in the Maritimes basin, eastern Canada. Water Resour Manage, 22, 1649-1675. DOI 10.1007/s11269-008-9247-7.

Straface S., Chidichimo F., Rizzo E., Riva M., Barrash W., Revil A., Cardiff M., GuadagniniA., 2011. Joint inversion of steady-state hydrologic and self-potential data for 3D hydraulic conductivity distribution at the Boise Hydrogeophysical Research Site. Journal of Hydrology 407, 115-128. doi:10.1016/j.jhydrol.2011.07.013

Taylor R. and Howard K., 2000. A tectono-geomorphic model of the hydrogeology of deeply weathered crystalline rock: evidence from Uganda. Hydrogeology J., 8 (3), 279-294.

Thiéry, D., 1993. Automatic calibration of groundwater models by the head gradient method. Groundwater quality management (Proceeding of the CQM 93 Conference at Talling). IAHS Publ, no 220.

Thiéry, D., 1994. Calibration of groundwater models by optimization of parameters in homogeneous geological zones. In Stochastic and statistical Methods in Hydrology and Environmental Engineering, Vol.2, 69-82. K.W. Hipel (ed.)

Thiéry, D., 2010. Groundwater flow modelling in porous media using MARTHE. In: Tanguy, J.M. (Ed.), Modelling Software Volume 5. Environmental Hydraulics Series. Editions Wiley/ISTE, London, pp. 45-60.

Thiéry, D., 2015. Code de calcul MARTHE - Modélisation 3D des écoulements dans les hydro-systèmes - Notice d'utilisation de la version 7.5, BRGM/RP-64554-FR, Orléans. 
936

937

938

939

940

941

942

943

944

945

946

947

948

949

950

951

952

953

954

955

956

Thiéry D., Amraoui N., Noyer M.-L., 2018. Modelling flow and heat transfer through unsaturated chalk - Validation with experimental data from the ground surface to the aquifer. J. of Hydrology, 556, 660-673. https://doi.org/10.1016/j.jhydrol.2017.11.041

Trushkin D.V., Shushakov O.A. and Legchenko A.V. 1994. The potential of a noise-reducing antenna for surface NMR ground water surveys in the earth's magnetic field. Geophysical Prospecting, 42, 855-862.

Tsang Y.W., Tsang C.F., Hale F.V. and Dverstorp B., 1996. Tracer transport in a stochastic continuum model of fractured media, Water Resour. Res., 32 (10), 3077-3092, doi:10.1029/96WR01397.

Vermeulen P.T.M., Heemink A. W., Valstar, J. R., 2005. Inverse modeling of groundwater flow using model reduction. Water Resour. Res., 41, W06003, doi:10.1029/2004WR003698.

Vouillamoz, J. M., Lawson, F. M. A., Yalob, N., Descloitres, M., 2014. The use of magnetic resonance sounding for quantifying specific yield and transmissivity in hard rock aquifers: The example of Benin. Journal of Applied Geophysics, 107, 16-24.

Wyns R., Baltassat J.M., Lachassagne P., Legchenko A., Vairon J. and Mathieu F., 2004. Application of SNMR soundings for groundwater reserves mapping in weathered basement rocks (Brittany, France), Bull. Soc. Géol. France, 175 (1), 21-34.

Yidana S.M Fynn O.F., Chegbeleh L.P., Nude P.M., Asiedu D.K., 2013. Hydrogeological conditions of a crystalline aquifer: simulation of optimal abstraction rates under scenarios of reduced recharge. The ScientificWorld Journal, Hindawi Publishing Corporation, Vol. 2013, Art. ID 606375, 8 pages. http://dx.doi.org/10.1155/2013/606375

957 
958

959

960

961

962

963

964

965

966

967

968

969

970

971

972

973

974

975

976

977

978

979

980

981

982

983

984

985

986

987

988

\section{Figure captions}

Figure 1. Topography and geology of a) Nançon and b) Maudouve-Noë Sèche watersheds with topographic levels (metres above sea level, contour interval: $10 \mathrm{~m}$ ), simplified geological map and groundwater abstraction.

Figure 2. The weathering profile of the Nançon watershed (Mougin et al., 2008). a) saprolites thickness map and b) total weathering profile thickness map (saprolites+fractured layer).

Figure 3. Nançon watershed. a) Water-table measurements and water-table map in August 2017 (metres above sea level), 500x500 m cell grid; black lines: faults; b) location of pumping tests, MRS measurements and streamflow rate measurements; c) variogram of water-table depth used for data interpolation (model: spherical, length: $900 \mathrm{~m}$, sill: 15.5), number near data points represents data pairs measurements, d) distribution on a logarithmic scale of the hydraulic conductivity of granitoïds in Brittany (fractured layer, n=104; BRGMdatabase, Mougin et al., 2016), vertical arrows show the hydraulic conductivity deduced from pumping tests in the Nançon area $(n=5)$, the inserted map shows the location of LogK estimates in Brittany. Stdev: standard deviation.

Figure 4. a) example of MRS measurements (NAN13A), left: estimated hydraulic conductivity vs. depth, right: estimated porosity vs. depth (corrected according to Vouillamoz et al., 2014); values on the graph present the average values for the layers, b) distribution on a logarithmic scale of the hydraulic conductivity deduced from MRS measurements $(n=16), c)$ plot of streamflow measurements according to watershed area. R: linear regression coefficient and d) distribution on a logarithmic scale of the hydraulic conductivity deduced from streamflow measurements $(\mathrm{n}=22)$. Nançon watershed.

Figure 5. a) Plot of water-table measurements (Aug. 2017) vs. elevation (in metres above sea level; masl), $n=342$. $R$ : linear regression coefficient, b) distribution on a logarithmic scale of the inverse-slope of the residual water-table map divided by the aquifer thickness (1/Slope/Aqui.thick.), c) resulting regionalized map and d) corresponding variogram (Model: exponential, length: $580 \mathrm{~m}$, sill: 0.087, nugget: 0.037). Nançon watershed.

Figure 6. a) Hydraulic conductivity map based on [1/Slope/Aqui.thick.] data, $\operatorname{LogK}(500 \mathrm{x}$ $500 \mathrm{~m}$ cells), b) comparison of the distribution on a logarithmic scale of the hydraulic conductivity data modelled with [1/Slope/Aqui.thick.] data, with those from granitoïds in 
989

990

991

992

993

994

995

996

997

998

999

1000

1001

1002

1003

1004

1005

1006

1007

1008

1009

1010

1011

1012

1013

1014

1015

1016

1017

1018

Brittany (Fig. 3d), R: linear regression coefficient between the two distributions and c) variogram of the hydraulic conductivity map (Model: spherical, length: $3000 \mathrm{~m}$, sill: 0.16, nugget: 0.3), number near data points represents data pairs measurements. Nançon watershed.

Figure 7. Numerical modelling on Nançon watershed (steady state), map resulting from the four hydraulic conductivity models tested, Row 1 to 4 : model 1 to model 4 . Column 1 to 3 : modelled water-levels and groundwater flow direction (a, d, g, k), bias between computed and measured water table (b, e, h, l), overflow of the water-table (c, f, i, m). Model 1 used the regionalized field (Fig. 6a), Model 2 used a uniform field (average value of Model 1, 3.9 $10^{-6}$ $\mathrm{m} / \mathrm{s}$ ), Model 3 used a field deduced from the inverse modelling of the observed water-table (Fig. 10a), and Model 4 used two zones of uniform hydraulic conductivity (Fig. 10c).

Figure 8. Comparison between observed and computed water-table. a) model 1, b) model 2, c) model 3, an d) model 4. Nançon watershed.

Figure 9. Comparison between measured streamflows and computed groundwater discharges to streams of the water-table. Nançon watershed.

Figure 10. a) Hydraulic conductivity field obtained by the numerical inversion of the watertable map in Log scale, it corresponds to Model 3, b) comparison of the distribution on a logarithmic scale of the hydraulic conductivity data from the inverse modelling, with those from the regionalization method (Fig. 6a) and c) Model 4, model with two zones of uniform hydraulic conductivity values. Nançon watershed.

Figure 11. a) Comparison of the hydraulic conductivity field obtained from the inverse modelling (Model 3) to that obtained from the regionalization method (Fig. 6a) and, b) statistical distribution of the relative deviation between $\operatorname{LogK}$ from the inverse model and LogK from the regionalization method. Nançon watershed.

Figure 12. Maudouve-Noë Sèche watershed. a) Water-table measurements and water-table map in August 2018 (metres above sea level); cells: 500x500m, b) hydraulic conductivity map deduced from the water-table map, c) comparison between measured streamflows and computed groundwater discharges to streams and d) comparison between observed and computed water-table (the insert shows statistical criteria). 


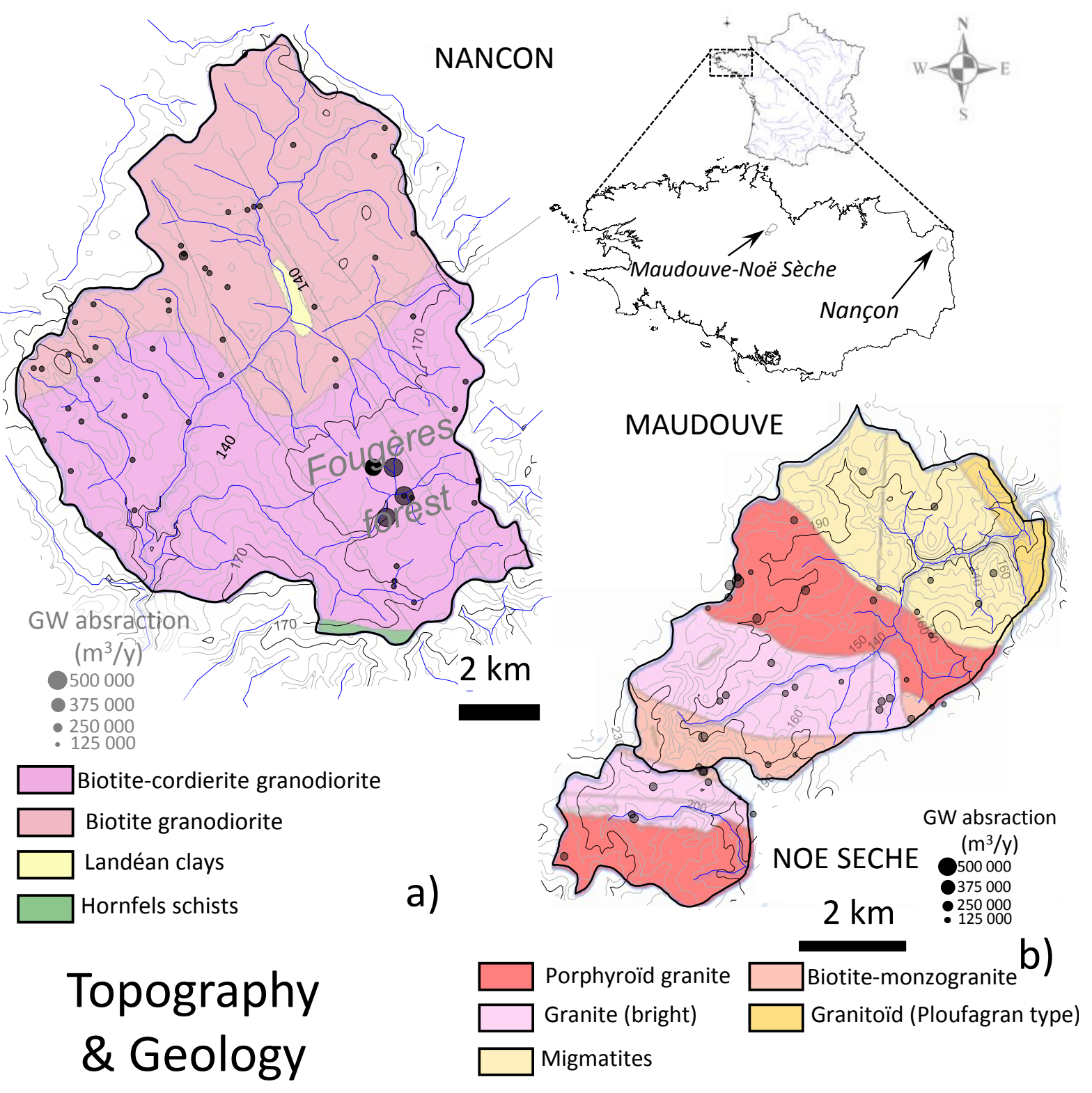

Figure 1 
Published in Journal of Hydrology (2021); https://doi.org/10.1016/j.jhydrol.2021.126652

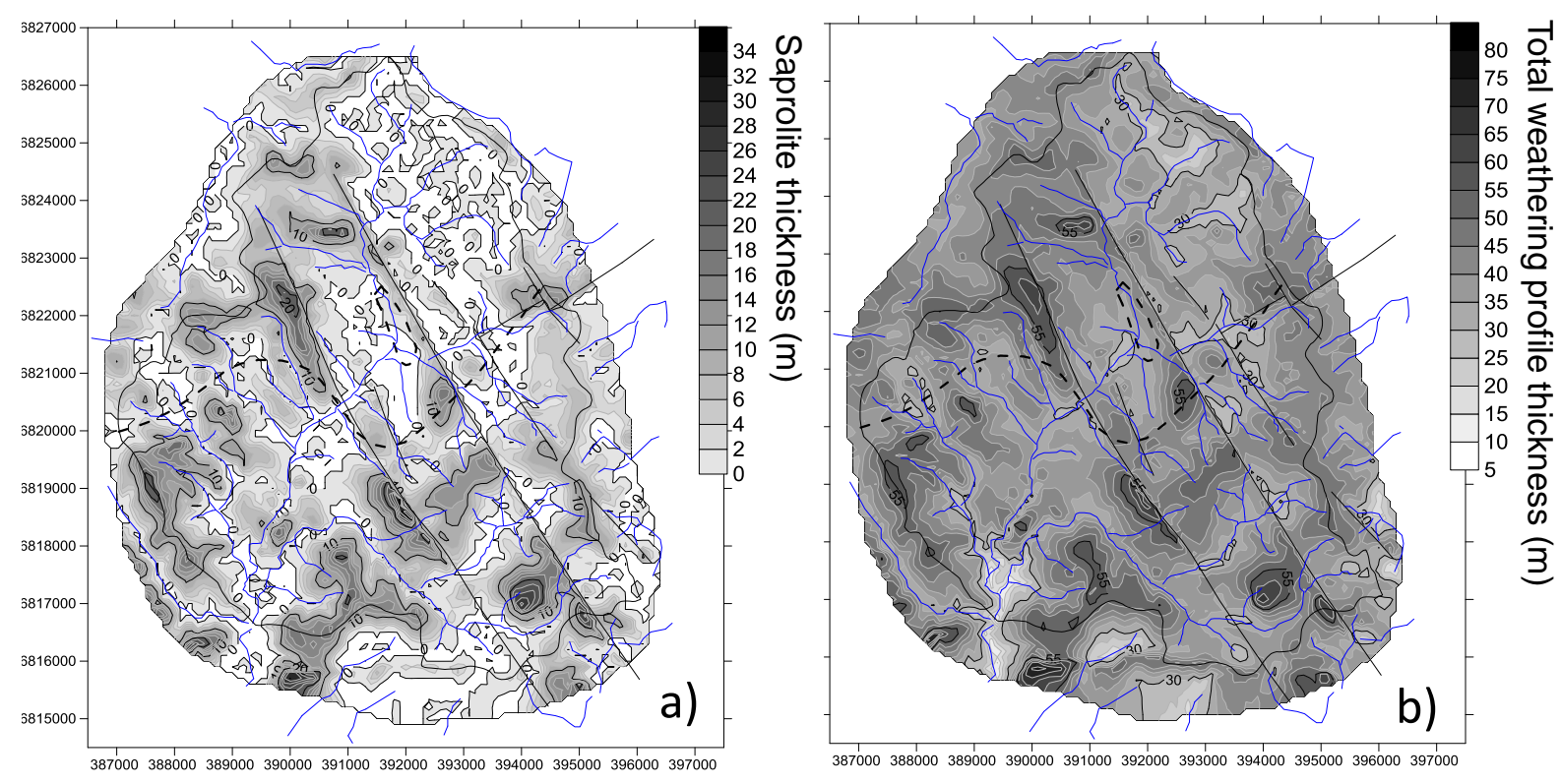

Figure 2 

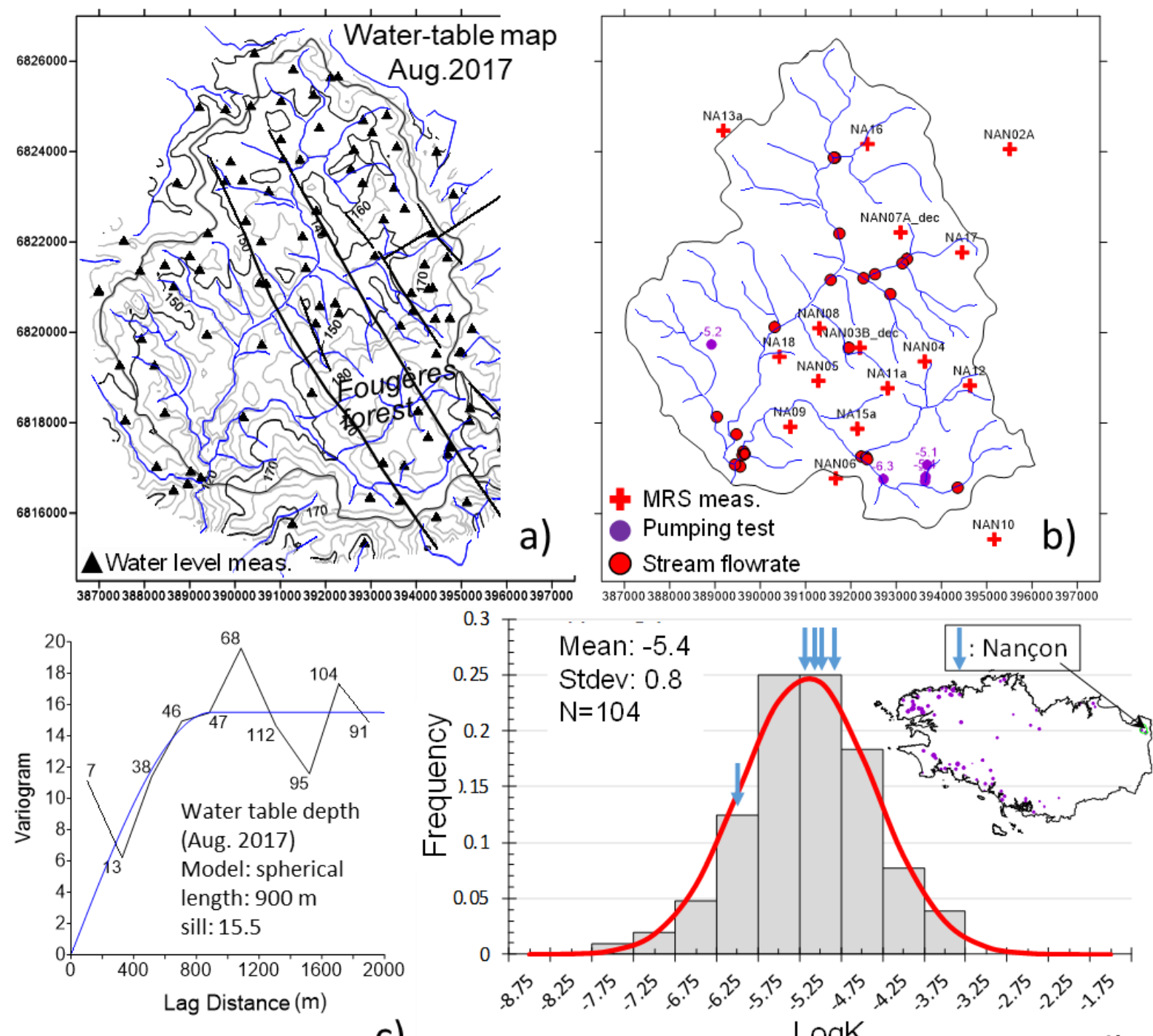

c) LogK

d)

\section{Figure 3}


Published in Journal of Hydrology (2021); https://doi.org/10.1016/j.jhydrol.2021.126652
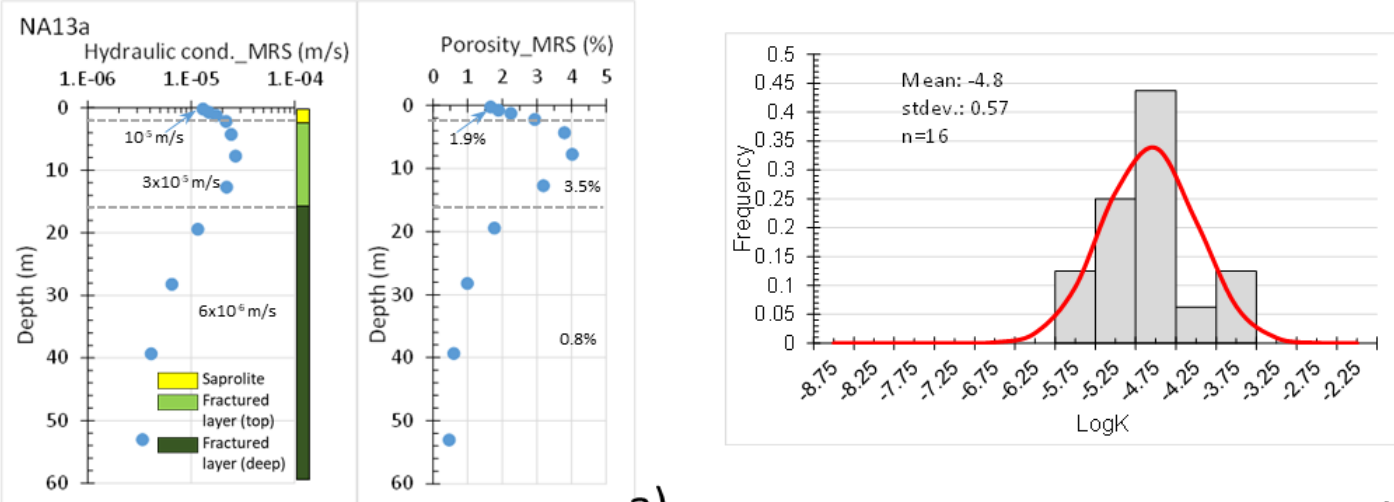

a)

b)
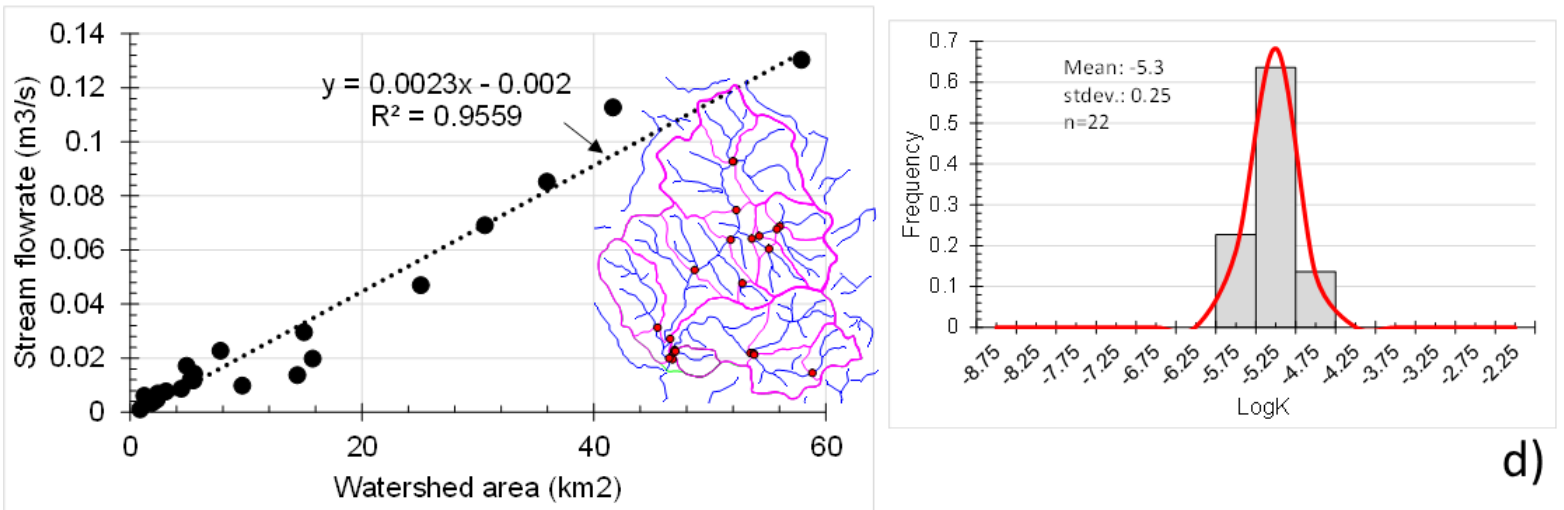

c)

Figure 4 
Published in Journal of Hydrology (2021); https://doi.org/10.1016/j.jhydrol.2021.126652
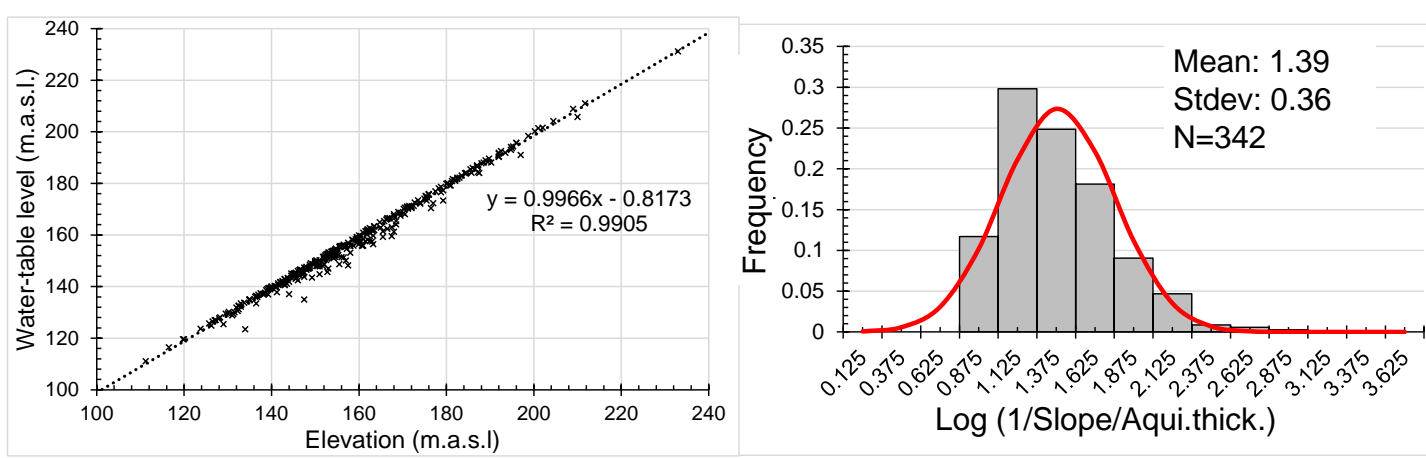

b)

a)

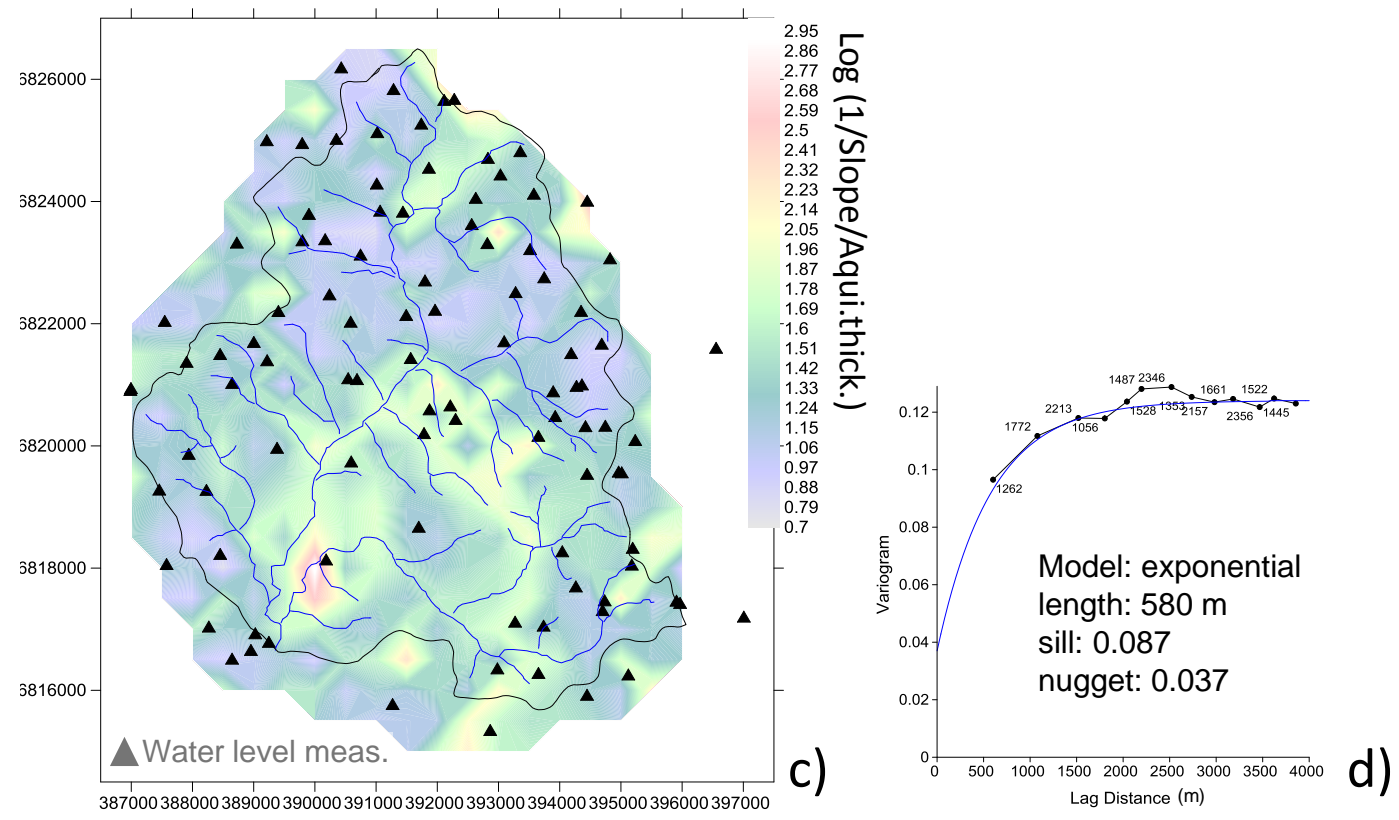

Figure 5 

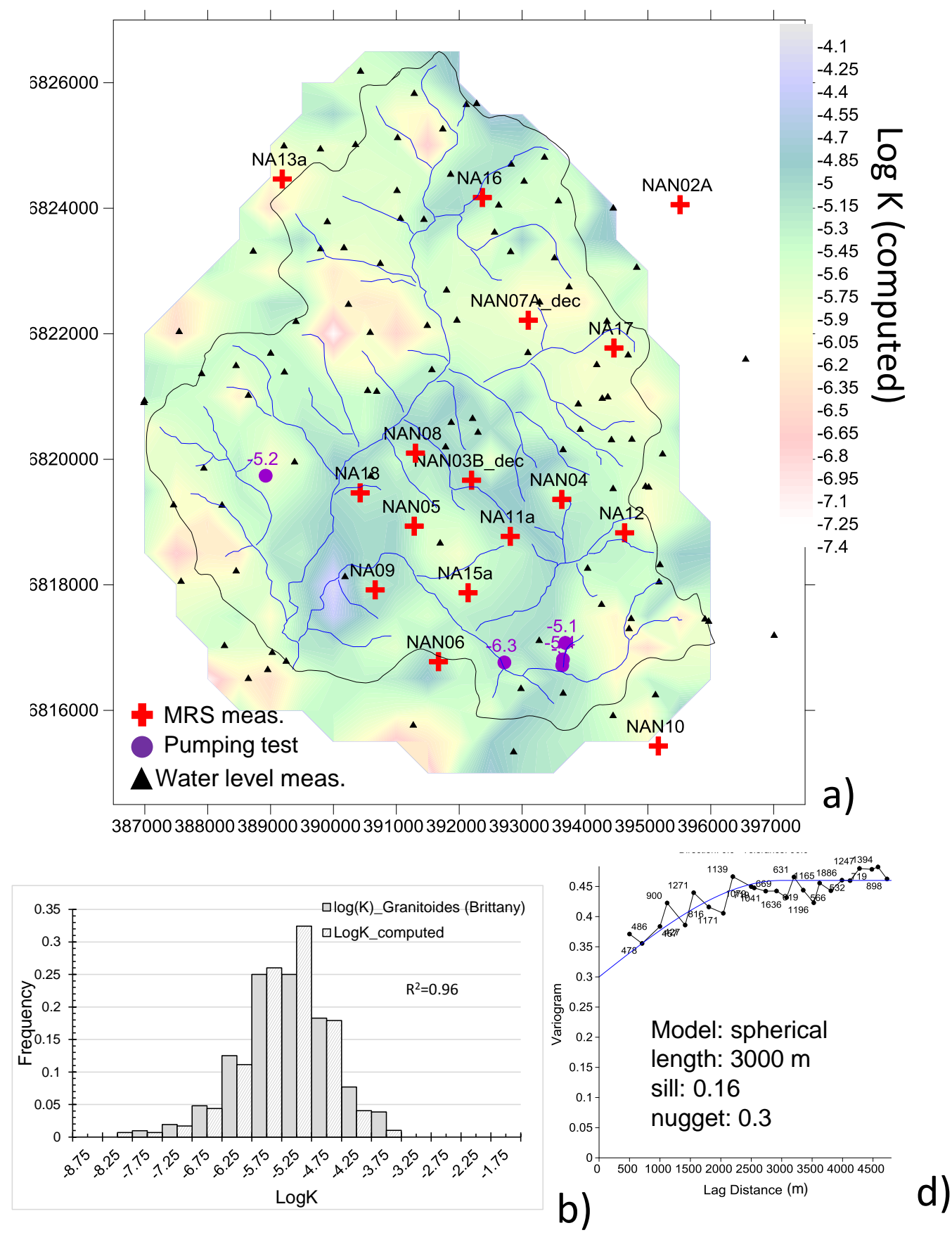

Figure 6 


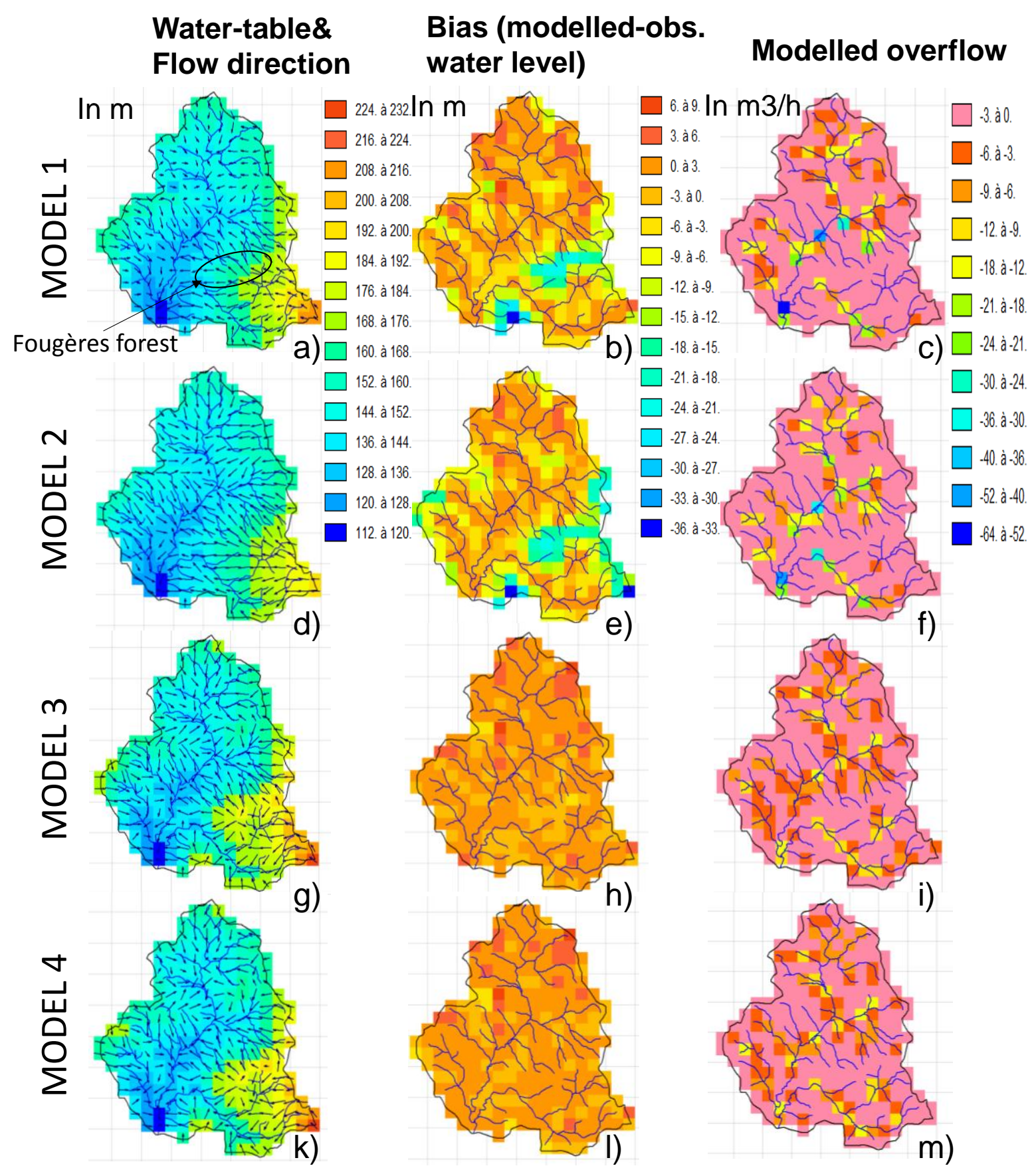

Figure 7 

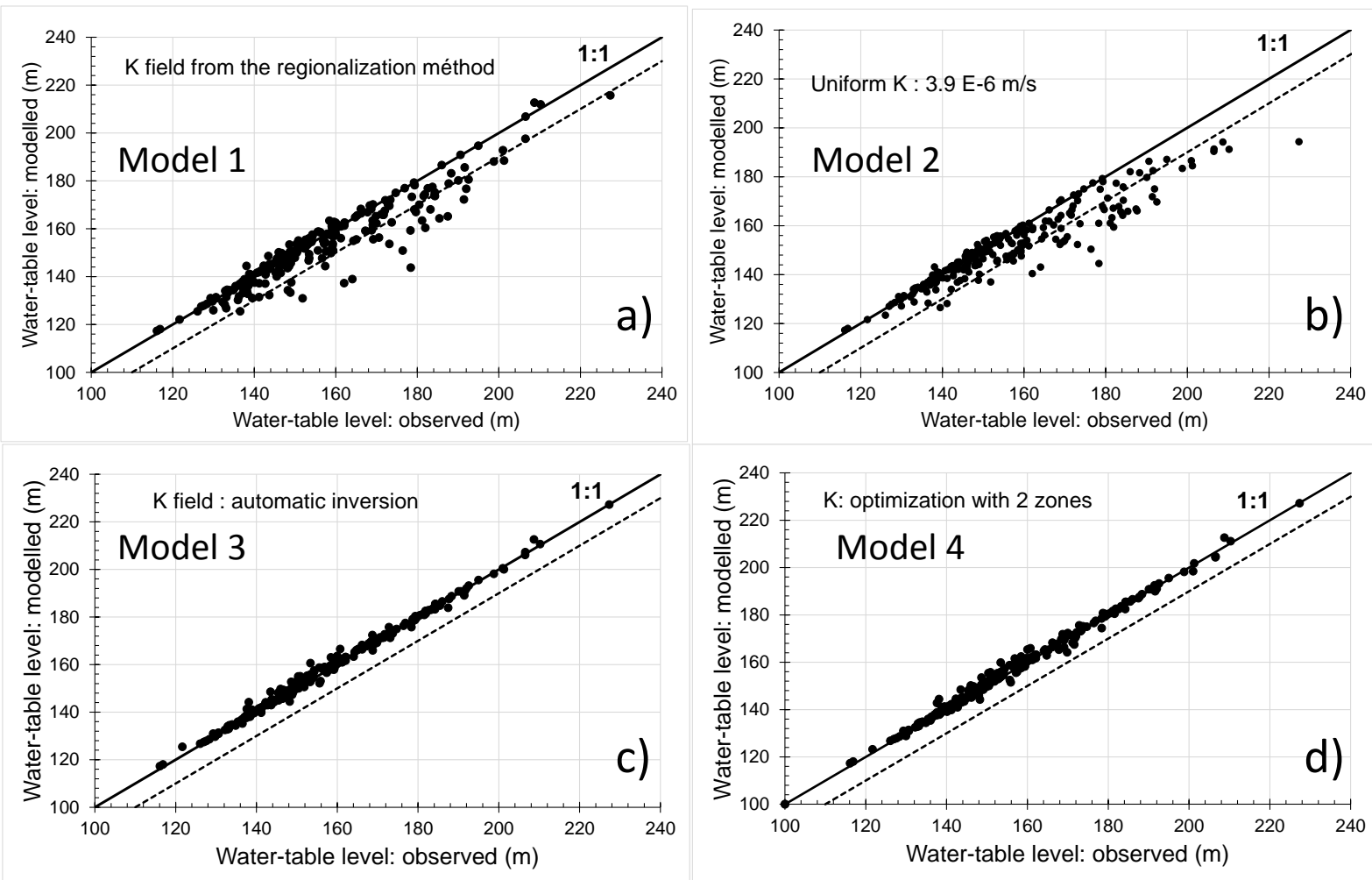

\section{Figure 8}

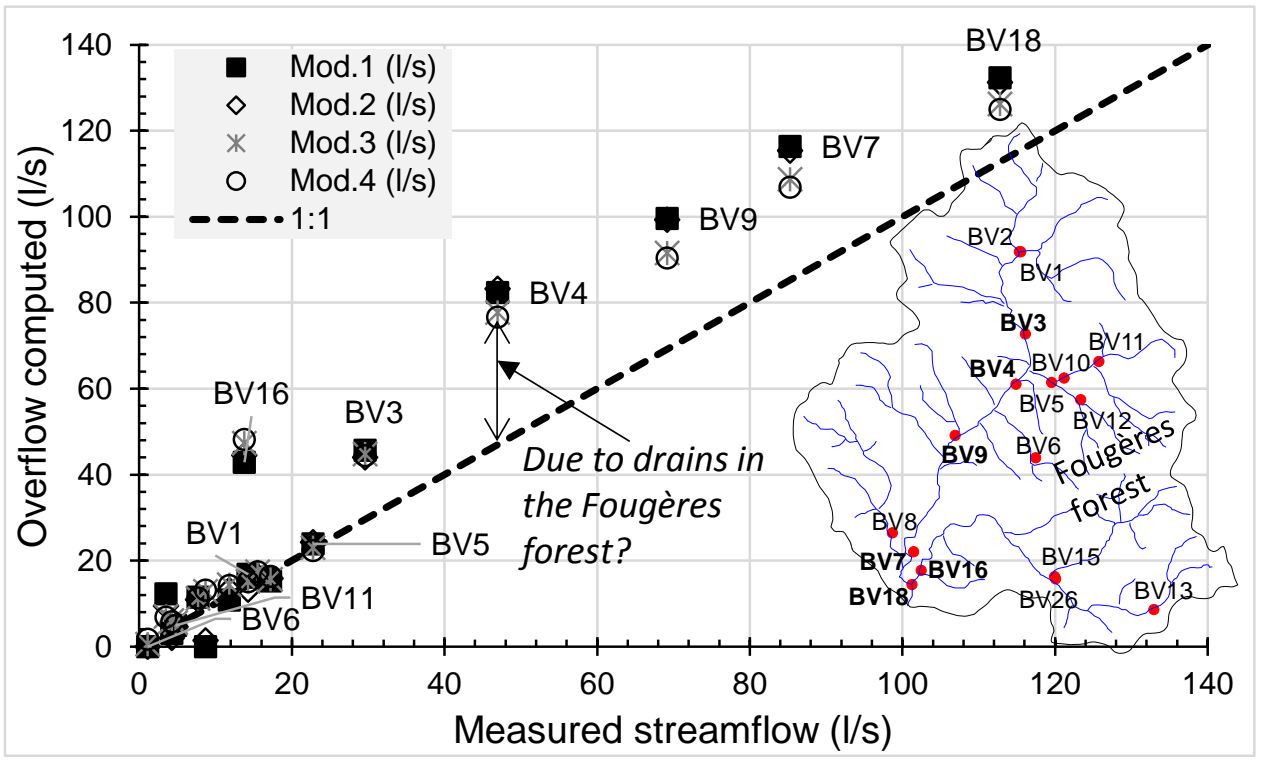

Figure 9 


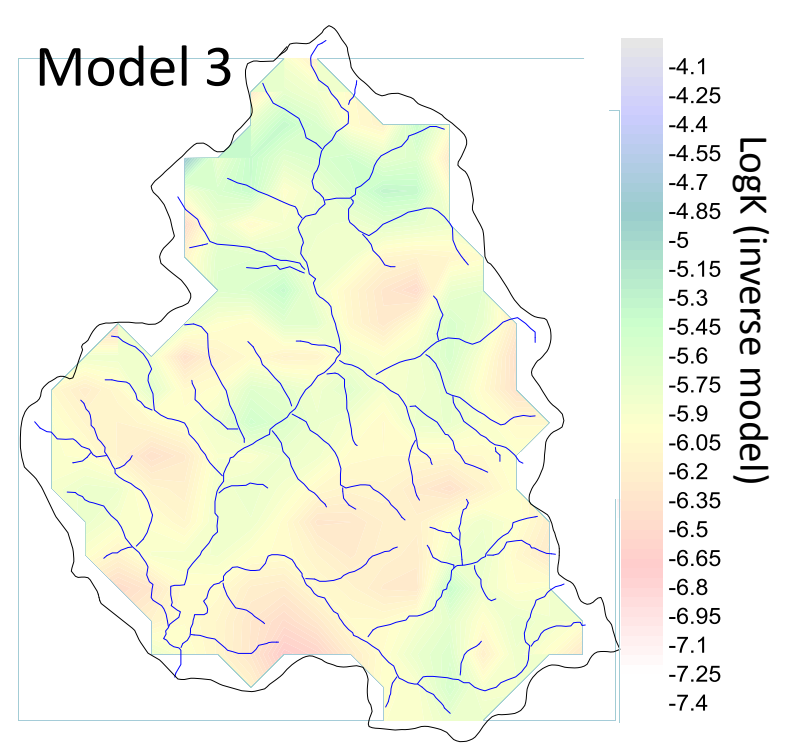

a)

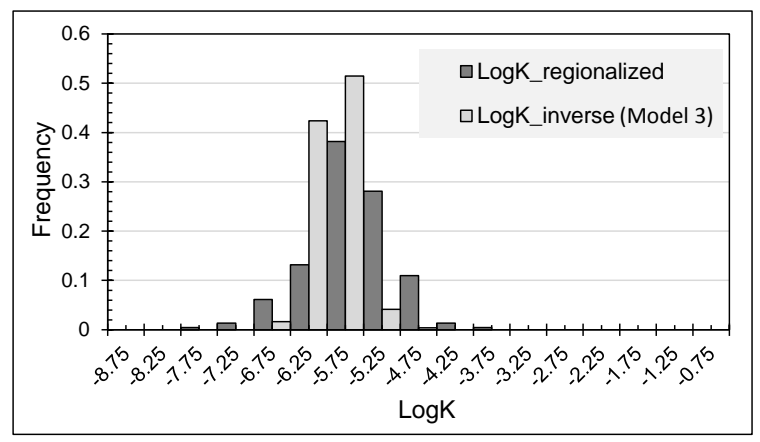

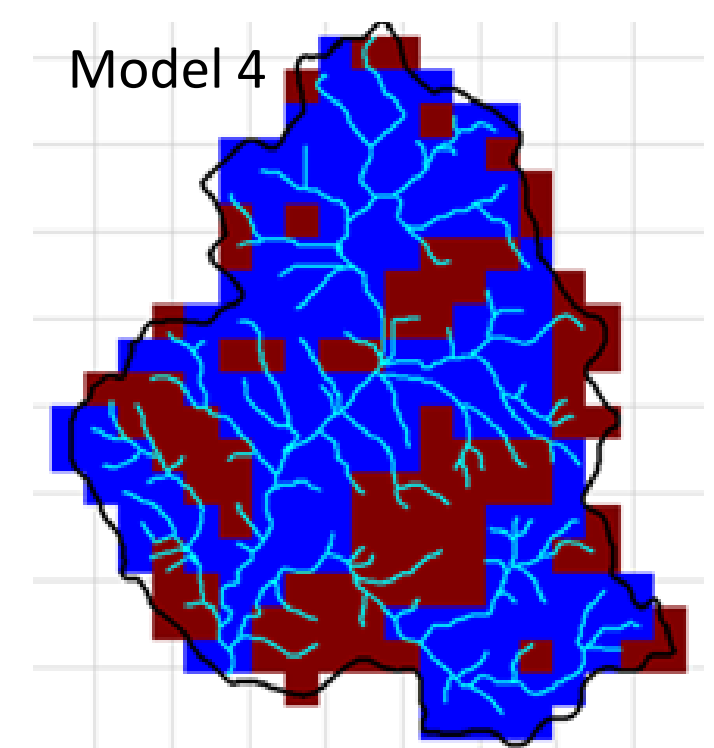

Zone 1

$\left(\mathrm{K}=2.1 \times 10^{-6} \mathrm{~m} / \mathrm{s}\right)$

Zone 2

$\left(K=3.3 \times 10^{-7} \mathrm{~m} / \mathrm{s}\right)$

b)

Figure 10 
Published in Journal of Hydrology (2021); https://doi.org/10.1016/j.jhydrol.2021.126652

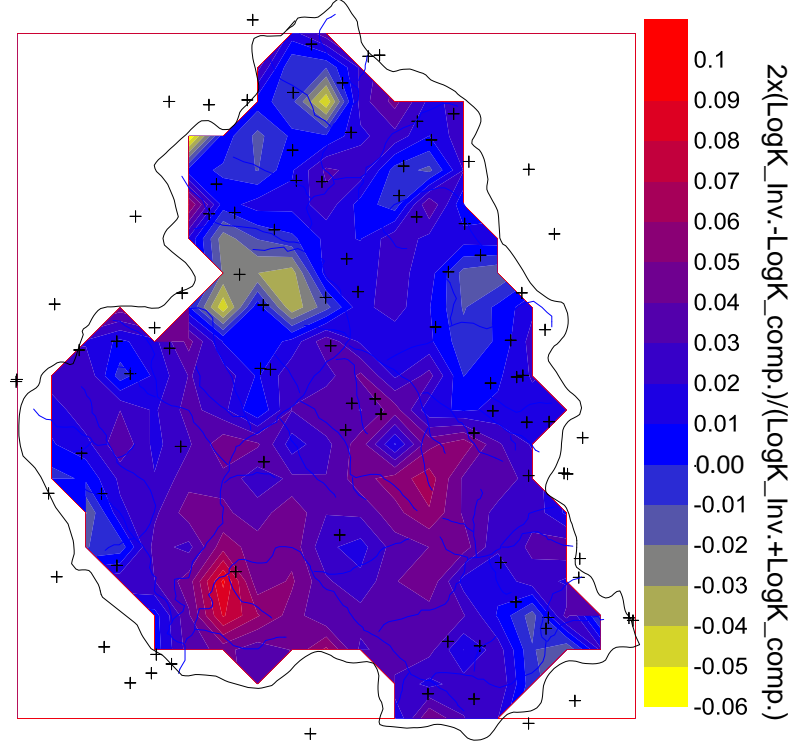

+ Water level meas.

a)

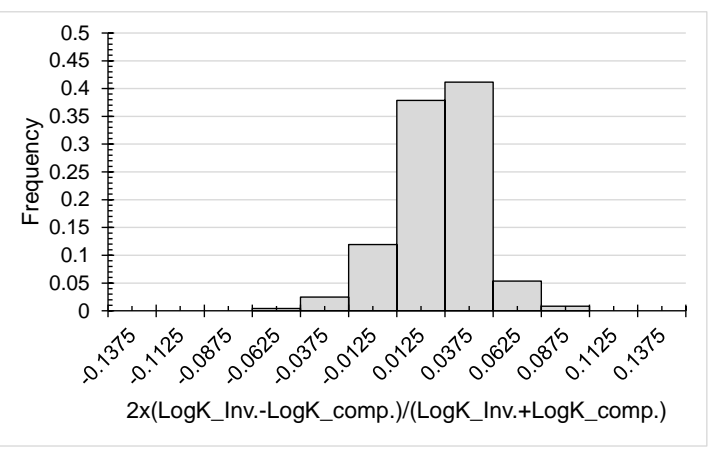

b)

Figure 11 


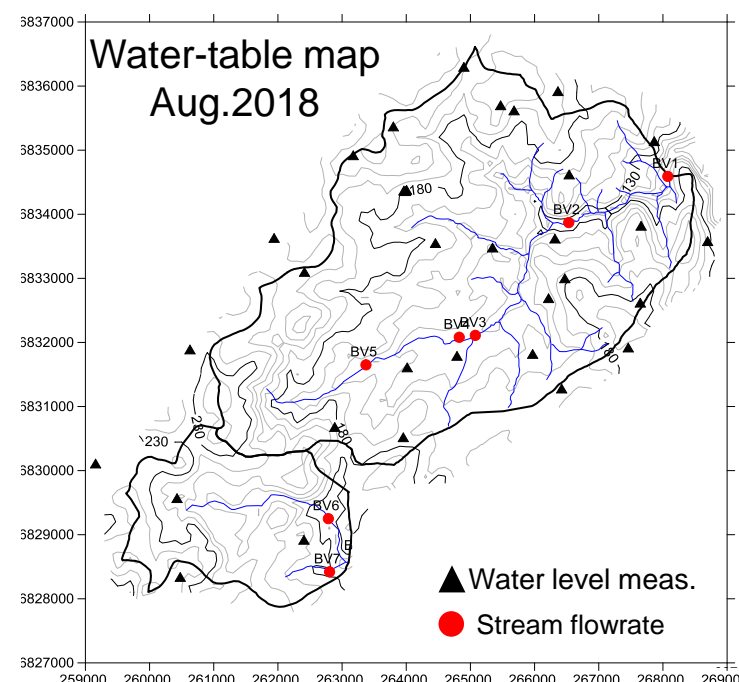

a)

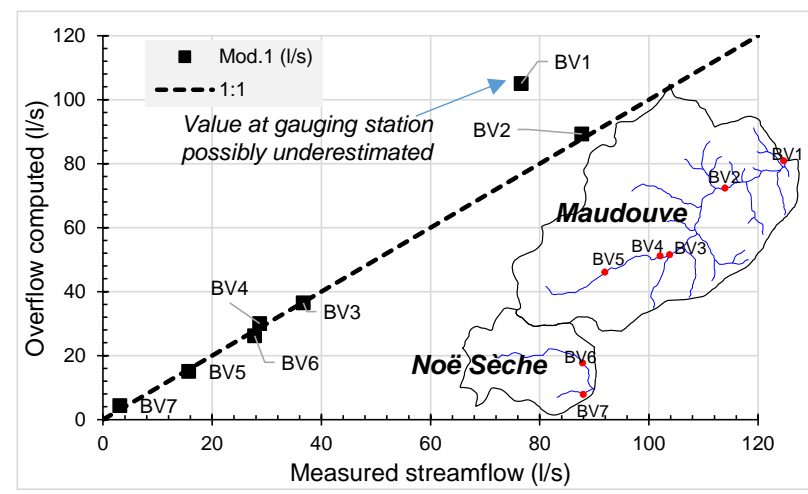

c)

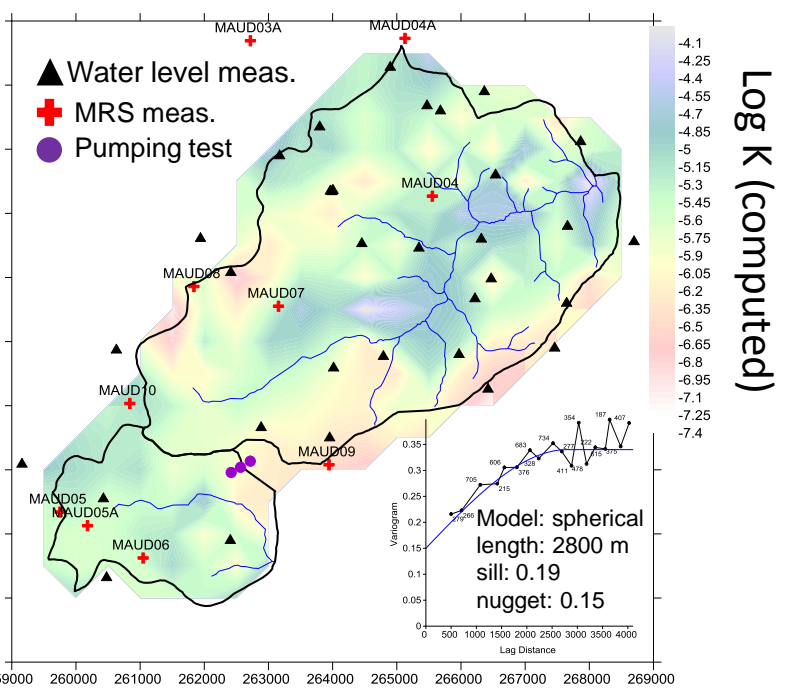

b)

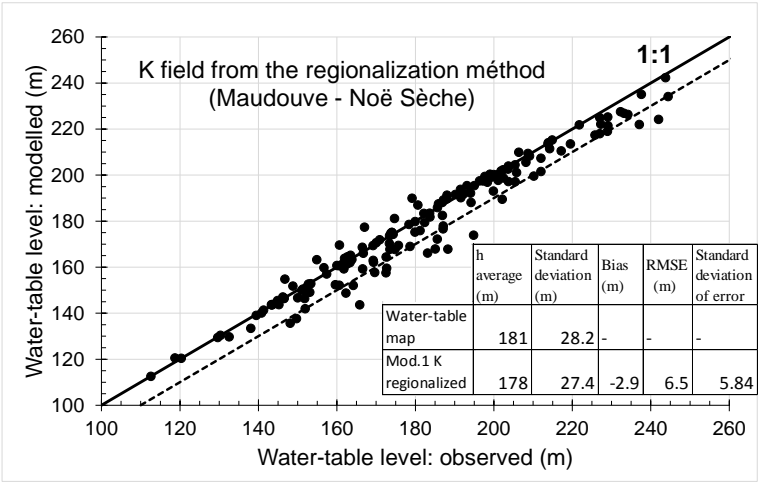

d)

Figure 12 
Published in Journal of Hydrology (2021); https://doi.org/10.1016/j.jhydrol.2021.126652

1036

1037

\begin{tabular}{|l|l|l|l|l|l|}
\hline & h average $(\mathrm{m})$ & Standard deviation $(\mathrm{m})$ & Bias $(\mathrm{m})$ & RMSE $(\mathrm{m})$ & $\begin{array}{l}\text { Standard deviation } \\
\text { of bias }(\mathrm{m})\end{array}$ \\
\hline Water-table map & 156.2 & 18.8 & - & - & - \\
\hline $\begin{array}{l}\text { Mod.1 } \\
\text { K regionalized }\end{array}$ & $153-(152)^{*}$ & $17-(16.4)^{*}$ & $-3.2-(-1.2)^{*}$ & $7.1-(3.7)^{*}$ & $6.4-(3.5)^{*}$ \\
\hline $\begin{array}{l}\text { Mod.2 } \\
\text { K uniform }\end{array}$ & 151.3 & 15 & -4.8 & 8.5 & 7.06 \\
\hline $\begin{array}{l}\text { Mod.3 } \\
\text { Inverse-modelling }\end{array}$ & 156.9 & 18.6 & 0.7 & 1.7 & 1.5 \\
\hline $\begin{array}{l}\text { Mod.4 } \\
\text { optimization with 2 } \\
\text { zones }\end{array}$ & 156.8 & 18.6 & 0.7 & 1.8 & 1.7 \\
\hline
\end{tabular}

1038

1039

1040

1041

1042

\section{Table}

Tableau 1: statistical criteria on water table for the four models of hydraulic conductivity. Bias: mean difference between the modelled and the observed water-table. RMSE: root mean square error.* if sectors where there is no water-table measurements are excluded. 


\section{Appendices}

Appendix A- Catchment-scale hydraulic conductivity deduced from stream base flow.

Considering an unconfined aquifer, where the bottom of the aquifer coincides with that of the stream (Fig. A), it can be shown from Boussinesq equation that at steady-state, hydraulic conductivity, $K$, can be deduced from (Dewandel et al., 2004):

$$
Q=3.448 K d r^{2} h^{2} A
$$

Where $Q$ is flowrate measurements, $A$ is the watershed area $\left(\mathrm{m}^{2}\right), h$ is the hydraulic head at the edge of the aquifer, $d r$ is the drainage density $(1 / \mathrm{m} ; d r=l / A$, with $l$ the length of perennial streams). For each sub-catchment $h$ is deduced from the mean hydraulic head gradient of the established water-table map $(\operatorname{grad} h=h / L)$. Using that procedure, basin-scale hydraulic conductivity was deduced for the 22 sub-catchments.

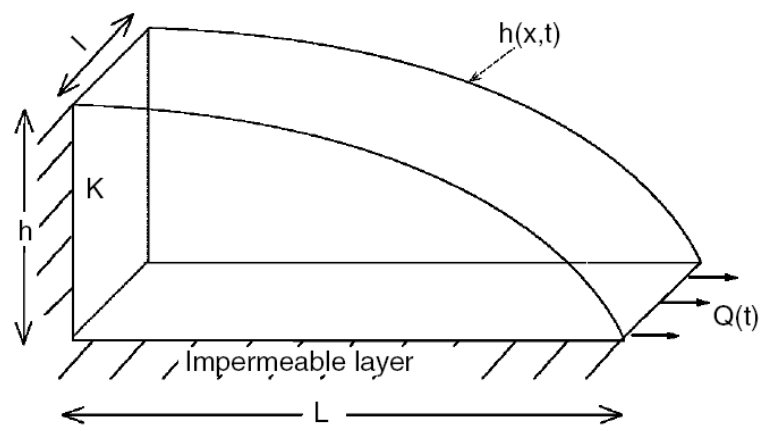

Figure A. Conceptual sketch of the Boussinesq aquifer.

Appendix B- Statistical distribution of the differences between LogK computed (regionalized hydraulic conductivity map, Fig 5a) from (1/slope/aqui.thick) and LogK estimated from a) hydraulic tests, b) MRS measurements in fractured layer, c) streamflow and d) scatter plot.
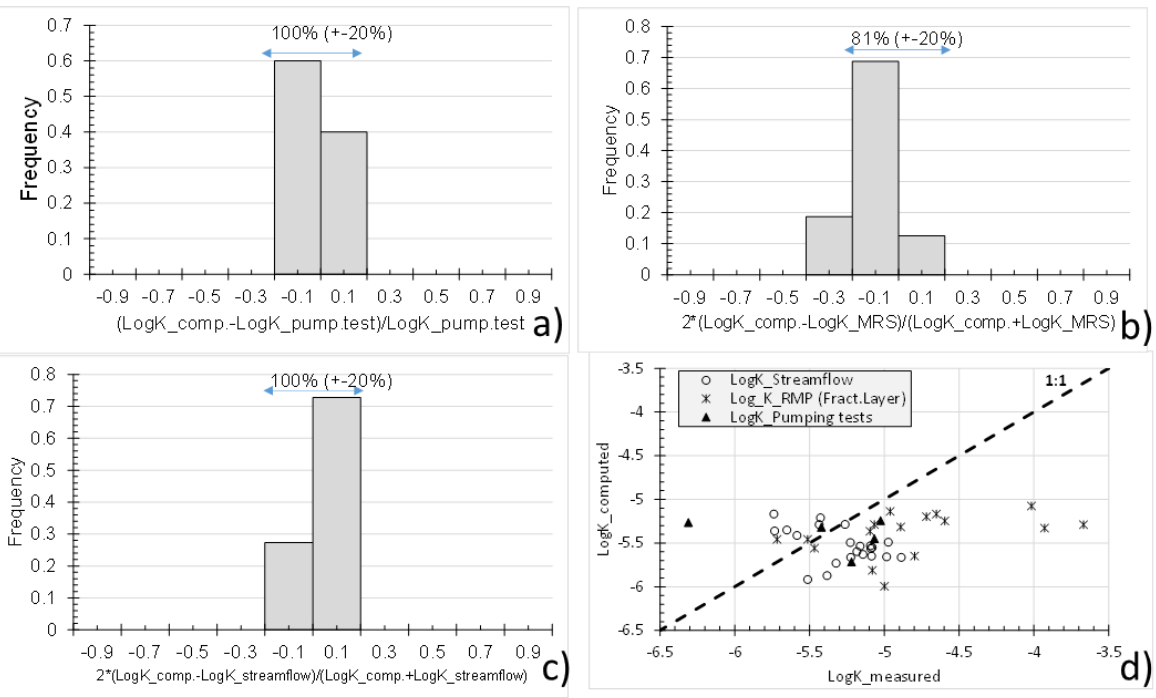